\title{
The Model of Emissions of Gases and Aerosols from Nature version 2.1 (MEGAN2.1): an extended and updated framework for modeling biogenic emissions
}

\author{
A. B. Guenther ${ }^{1}$, X. Jiang ${ }^{1}$, C. L. Heald ${ }^{2}$, T. Sakulyanontvittaya ${ }^{3}$, T. Duhl ${ }^{1}$, L. K. Emmons ${ }^{1}$, and X. Wang ${ }^{4}$ \\ ${ }^{1}$ Atmospheric Chemistry Division, NCAR Earth System Laboratory, Boulder, CO, USA \\ ${ }^{2}$ Department of Civil and Environmental Engineering, Massachusetts Institute of Technology, Cambridge, MA, USA \\ ${ }^{3}$ ENVIRON, Novato, CA, USA \\ ${ }^{4}$ School of Environmental Science and Engineering, Sun Yat-sen University, Guangzhou 510275, China
}

Correspondence to: A. B. Guenther (guenther@ucar.edu)

Received: 9 May 2012 - Published in Geosci. Model Dev. Discuss.: 12 June 2012

Revised: 3 October 2012 - Accepted: 9 October 2012 - Published: 26 November 2012

\begin{abstract}
The Model of Emissions of Gases and Aerosols from Nature version 2.1 (MEGAN2.1) is a modeling framework for estimating fluxes of biogenic compounds between terrestrial ecosystems and the atmosphere using simple mechanistic algorithms to account for the major known processes controlling biogenic emissions. It is available as an offline code and has also been coupled into land surface and atmospheric chemistry models. MEGAN2.1 is an update from the previous versions including MEGAN2.0, which was described for isoprene emissions by Guenther et al. (2006) and MEGAN2.02, which was described for monoterpene and sesquiterpene emissions by Sakulyanontvittaya et al. (2008). Isoprene comprises about half of the total global biogenic volatile organic compound (BVOC) emission of $1 \mathrm{Pg}$ $\left(1000 \mathrm{Tg}\right.$ or $\left.10^{15} \mathrm{~g}\right)$ estimated using MEGAN2.1. Methanol, ethanol, acetaldehyde, acetone, $\alpha$-pinene, $\beta$-pinene, $t$ - $\beta$ ocimene, limonene, ethene, and propene together contribute another $30 \%$ of the MEGAN2.1 estimated emission. An additional 20 compounds (mostly terpenoids) are associated with the MEGAN2.1 estimates of another $17 \%$ of the total emission with the remaining 3\% distributed among $>100$ compounds. Emissions of 41 monoterpenes and 32 sesquiterpenes together comprise about $15 \%$ and $3 \%$, respectively, of the estimated total global BVOC emission. Tropical trees cover about $18 \%$ of the global land surface and are estimated to be responsible for $\sim 80 \%$ of terpenoid emissions and $\sim 50 \%$ of other VOC emissions. Other trees cover about the same area but are estimated to contribute
\end{abstract}

only about $10 \%$ of total emissions. The magnitude of the emissions estimated with MEGAN2.1 are within the range of estimates reported using other approaches and much of the differences between reported values can be attributed to land cover and meteorological driving variables. The of fline version of MEGAN2.1 source code and driving variables is available from http://bai.acd.ucar.edu/MEGAN/ and the version integrated into the Community Land Model version 4 (CLM4) can be downloaded from http://www.cesm. ucar.edu/.

\section{Introduction}

Terrestrial ecosystems produce a diverse array of chemicals including many volatile and semi-volatile compounds that are emitted into the atmosphere (Goldstein and Galbally, 2007). Some of these have an important role in atmospheric chemistry including reactive volatile organic compounds (VOC) for which terrestrial ecosystems are by far the biggest contributors to the global annual flux (Lamarque et al., 2010). It is now widely recognized that these chemicals can influence atmospheric composition and quantitative estimates of their emissions into the atmosphere are needed for numerical assessments of past, present and future air quality and climate (e.g., Derwent et al., 2007; Folberth et al., 2006). Isoprene and a few other biogenic VOC (BVOC), in some cases including total monoterpenes, are now routinely 
included in air quality and earth system numerical models but the magnitude and variability of these emissions are not well known (e.g., Derwent et al., 2007; Folberth et al., 2006). Other known biogenic compounds are simply omitted from these models. This could be because they are considered unimportant or because no emission model approaches have been developed for these compounds.

The Model of Emissions of Gases and Aerosols from Nature version 2.1 (MEGAN2.1) is used to estimate emissions of compounds from urban, rural and agricultural ecosystems that can influence the atmosphere. MEGAN2.1 has been updated from MEGAN2.0 (Guenther et al., 2006) and MEGAN2.02 (Sakulyanontvittaya et al., 2008) to include additional compounds, emission types, and controlling processes. MEGAN has simple mechanistic algorithms that account for the major known processes controlling biogenic emissions. MEGAN is a global model with $1 \mathrm{~km}$ (or less) spatial resolution that can be used for both regional air quality modeling and global earth system modeling studies. Emissions can be estimated using different weather and land cover data, and the model results are very sensitive to these driving variables (Guenther et al., 2006; Pfister et al., 2008; Arneth et al., 2011).

Goldstein and Galbally (2007) estimate that tens of thousands of VOC have been measured in the atmosphere and speculate that there may be hundreds of thousands more that have not been measured. Most of these compounds are atmospheric oxidation products but a substantial number are direct emissions. A list of 367 compounds known to be emitted by vegetation was compiled by Graedel (1979) more than three decades ago and the list has grown longer since then. Previous BVOC emission models (e.g., Lamb et al., 1987; Guenther et al., 1995) included one or several "other VOC" categories in an attempt to be comprehensive. This approach was of limited use for atmospheric chemistry modeling since these "other VOC" could not be converted into the categories used in various chemical schemes. It was not even clear how to make unit conversions from mass to moles since the average molecular weight of "other VOC" was not known. To eliminate this issue, MEGAN2.1 does not include an "other VOC" category and instead includes emissions of $\sim 150$ specific compounds (see Table 1). This list includes all reported significant emissions with the exception of those compounds observed only in floral scents. MEGAN also includes schemes for converting each of these compounds into some of the common reaction schemes used in atmospheric chemistry models including CB4, CB05, and SAPRC99 (see http://bai.acd.ucar.edu/MEGAN/). Compounds with the same emission activity parameterizations are grouped into emission categories to minimize computational requirements. In many cases, compounds are assigned the same emission activity parameterizations simply because the values are not well known.

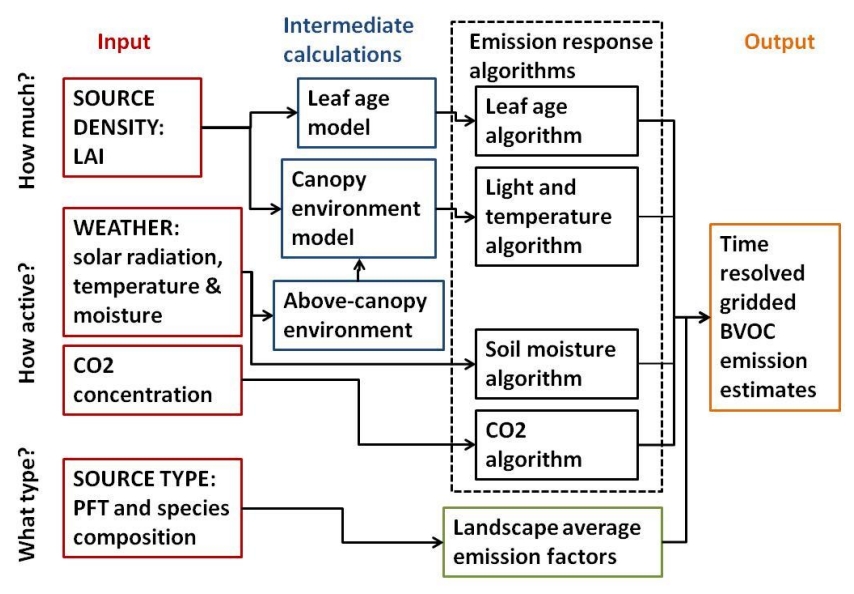

Fig. 1. Schematic of MEGAN2.1 model components and driving variables.

\section{Model description}

The MEGAN emission rates represent the sum of all emission sources that can naturally occur in a terrestrial ecosystem, even though these emissions may have changed due to human activities. Important exceptions include biomass burning which is the focus of a companion model, Fire Inventory from NCAR (FINN; Wiedinmyer et al., 2011), and animal feedlots. Foliage is the dominant global BVOC source but emissions from woody tissues, roots, fruits and flowers make important contributions for some compounds and more research is needed to quantify these sources (Fall, 1999).

MEGAN2.1 is available as an offline code and as an integrated component of land surface and atmospheric chemistry models. The offline code is referred to here as the WRF-AQ (Weather Research and Forecasting-Air Quality) version and is available, along with driving variables and a test case, to be downloaded (see http://bai.acd.ucar.edu/MEGAN/). The WRF-AQ version uses WRF (or MM5) meteorological data and provides emissions in a format suitable for input to the CMAQ (Community Multi-scale Air Quality) and CAMx (Comprehensive Air Quality Model with Extensions) regional air quality models. MEGAN2.1 has also been embedded into the Community Land Model (CLM4.0; Lawrence et al., 2011) which can run offline or as an on-line component of the Community Earth System Model (CESM; Gent et al., 2011) which includes the chemistry model CAM-chem (Lamarque et al., 2012). Emissions of select species following the MEGAN2.1 approach have also been integrated into global atmospheric chemistry models including GEOSChem v9 (Millet et al., 2010) and IMAGES2 (Stavrakou et al., 2011).

A schematic of the MEGAN2.1 model is shown in Fig. 1. The two major model components are the algorithms describing emission response to variations in environmental conditions and the calculation of landscape average emission 
Table 1. MEGAN2.1 compound classes and individual compounds.

\begin{tabular}{ll}
\hline Compound Class & Compound names \\
\hline isoprene & isoprene \\
myrcene & myrcene \\
sabinene & sabinene \\
limonene & limonene \\
3 -carene & 3 -carene \\
$t$ - $\beta$-ocimene & $t$ - $\beta$-ocimene \\
$\alpha$-pinene & $\alpha$-pinene \\
$\beta$-pinene & $\beta$-pinene \\
$\beta$-caryophyllene & $\beta$-caryophyllene \\
$\alpha$-farnesene & $\alpha$-farnesene \\
232 -MBO & 232 -MBO \\
methanol & methanol \\
acetone & acetone \\
CO & CO
\end{tabular}

Other Monoterpenes (34 compounds)

aromatic monoterpenes (dimethyl styrene, meta-cymenene, p-cymene, and o-cymene), monoterpenes $(\alpha$-phellandrene, $\alpha$-thujene, $\alpha$-terpinene, $\gamma$-terpinene, terpinolene, $\beta$ phellandrene, camphene, bornene, $\alpha$-fenchene, allo-ocimene, cis- $\beta$-ocimene, verbenene and tricyclene), oxygenated monoterpenes (camphor, fenchone, piperitone, myrtenal, $\alpha$-thujone, $\beta$-thujone, 1,8-cineole, borneol, linalool, 4-terpineol, $\alpha$-terpineol, cis-linalool oxide, translinaool oxide and bornyl acetate) and monoterpenoid-related compounds ( $\beta$-ionone, ipsenol and estragole).

Other Sesquiterpenes category (30 compounds)

Bidirectional VOC (5 compounds) Stress VOC (15 compounds)

Other VOC (49 compounds) sesquiterpenes ( $\alpha$-bergamotene, $\beta$-bisabolene, $\beta$-farnesene, $\alpha$-humulene, acoradiene, aromadendrene, $\beta$-bergamotene, $\alpha$-bisabolene, $\beta$-bourbonene, $\delta$-cadinene, $\delta$-cadinene, $\alpha$-cedrene, $\alpha$-copaene, $\alpha$-cubebene, $\beta$-cubebene, $\beta$-elemene, germacrene $\mathrm{B}$, germacrene $\mathrm{D}, \beta$-gurjunene, $\gamma$-humulene, isolongifolene, longifolene, longipinene, $\alpha$-muurolene, $\gamma$-muurolene, $\beta$-selinene, and $\delta$-selinene), oxygenated sesquiterpenes (cis-nerolidol, trans-nerolidol and cedrol).

ethanol, acetaldehyde, formaldehyde, acetic acid, formic acid

ethene, dimethyl-nonatriene (DMNT), 3-hexenal, 2-hexenal, 3-hexenol, 3-hexenyl acetate, hydrogen cyanide, hexanal, 1-hexenol, methyl jasmonate, methyl salicylate, toluene, indole, trimethyl-tridecatetraene (TMTT), jasmone

leaf surface compounds (homosalate, 2-ethylhexyl salicylate, geranyl acetone, oxopentanal, and methyl heptenone), organic halides (methyl bromide, methyl chloride and methyl iodide), sulfur compounds (diallyl disulfide, methyl propenyl disulfide, propenylpropyldisulfide, carbon disulfide, carbonyl sulfide, hydrogen sulfide, methyl mercapten, dimethyl sulfide and dimethyl disulfide), alkanes (methane, ethane, propane, pentane, hexane, heptane), alkenes (butene, propene, 1-dodecene, 1-tetradecene), benzenoids (benzaldehyde, methyl benzoate, 2phenylacetaldehyde, eugenol, anisole, benzyl acetate, benzyl alcohol, and naphthalene), oxygenated VOC (pentanal, hexanal, heptanal, octanal, nonanal, decanal, octanol, octenol, heptanone, 2-butanone, pyruvic acid, 331-methylbutenol, 321-methylbutenol, neryl acetone, $\alpha$ terpinyl acetate, phenylacetaldehyde and nonenal) factors. MEGAN2.1 estimates emissions $\left(F_{i}\right)$ of chemical species $i$ from terrestrial landscapes as the product of these two components in units of $\left(\mu \mathrm{g} \mathrm{m}^{-2} \mathrm{~h}^{-1}\right)$ for 19 compound classes $(i)$ according to

$F_{i}=\gamma_{i} \sum \varepsilon_{i, j} \chi_{j}$

where $\varepsilon_{i, j}$ is the emission factor at standard conditions for vegetation type $j$ with fractional grid box areal coverage $\chi_{j}$. The emission activity factor $\left(\gamma_{i}\right)$ accounts for the processes controlling emission responses to environmental and phenological conditions. The 19 categories are used to estimate inputs for common atmospheric chemistry schemes by first decomposing into 147 individual compounds and then lumping into the appropriate categories for the chemical scheme. The following section describes the emission factors (Sect. 2.1), emission algorithms (Sect. 2.2), the observations used to parameterize the model (Sect. 2.3), intermediate models used to process the driving variables (Sect. 2.4) and the driving variables (Sect. 2.5).

\subsection{Emission factors}

Guenther et al. (2006) provided multiple options for defining MEGAN2.0 emission types in recognition of the different 
Table 2. MEGAN2.1 biogenic emission classes and emission factors $\left(\mu \mathrm{g} \mathrm{m} \mathrm{m}^{-2} \mathrm{~h}^{-1}\right)$ for each of the plant functional types described in Table 3 .

\begin{tabular}{|c|c|c|c|c|c|c|c|c|c|c|c|c|c|c|c|}
\hline Compound Class & $\mathrm{EF}_{1}$ & $\mathrm{EF}_{2}$ & $\mathrm{EF}_{3}$ & $\mathrm{EF}_{4}$ & $\mathrm{EF}_{5}$ & $\mathrm{EF}_{6}$ & $\mathrm{EF}_{7}$ & $\mathrm{EF}_{8}$ & $\mathrm{EF}_{9}$ & $\mathrm{EF}_{10}$ & $\mathrm{EF}_{11}$ & $\mathrm{EF}_{12}$ & $\mathrm{EF}_{13}$ & $\mathrm{EF}_{14}$ & $\mathrm{EF}_{15}$ \\
\hline Isoprene & 600 & 3000 & 1 & 7000 & 10000 & 7000 & 10000 & 11000 & 2000 & 4000 & 4000 & 1600 & 800 & 200 & 1 \\
\hline Myrcene & 70 & 70 & 60 & 80 & 30 & 80 & 30 & 30 & 30 & 50 & 30 & 0.3 & 0.3 & 0.3 & 0.3 \\
\hline Sabinene & 70 & 70 & 40 & 80 & 50 & 80 & 50 & 50 & 50 & 70 & 50 & 0.7 & 0.7 & 0.7 & 0.7 \\
\hline Limonene & 100 & 100 & 130 & 80 & 80 & 80 & 80 & 80 & 60 & 100 & 60 & 0.7 & 0.7 & 0.7 & 0.7 \\
\hline 3-Carene & 160 & 160 & 80 & 40 & 30 & 40 & 30 & 30 & 30 & 100 & 30 & 0.3 & 0.3 & 0.3 & 0.3 \\
\hline$t$ - $\beta$-Ocimene & 70 & 70 & 60 & 150 & 120 & 150 & 120 & 120 & 90 & 150 & 90 & 2 & 2 & 2 & 2 \\
\hline$\beta$-Pinene & 300 & 300 & 200 & 120 & 130 & 120 & 130 & 130 & 100 & 150 & 100 & 1.5 & 1.5 & 1.5 & 1.5 \\
\hline$\alpha$-Pinene & 500 & 500 & 510 & 600 & 400 & 600 & 400 & 400 & 200 & 300 & 200 & 2 & 2 & 2 & 2 \\
\hline Other Monoterpenes & 180 & 180 & 170 & 150 & 150 & 150 & 150 & 150 & 110 & 200 & 110 & 5 & 5 & 5 & 5 \\
\hline$\alpha$-Farnesene & 40 & 40 & 40 & 60 & 40 & 60 & 40 & 40 & 40 & 40 & 40 & 3 & 3 & 3 & 4 \\
\hline$\beta$-Caryophyllene & 80 & 80 & 80 & 60 & 40 & 60 & 40 & 40 & 50 & 50 & 50 & 1 & 1 & 1 & 4 \\
\hline Other Sesquiterpenes & 120 & 120 & 120 & 120 & 100 & 120 & 100 & 100 & 100 & 100 & 100 & 2 & 2 & 2 & 2 \\
\hline 232-MBO & 700 & 60 & 0.01 & 0.01 & 0.01 & 0.01 & 0.01 & 2 & 0.01 & 0.01 & 0.01 & 0.01 & 0.01 & 0.01 & 0.01 \\
\hline Methanol & 900 & 900 & 900 & 500 & 900 & 500 & 900 & 900 & 900 & 900 & 900 & 500 & 500 & 500 & 900 \\
\hline Acetone & 240 & 240 & 240 & 240 & 240 & 240 & 240 & 240 & 240 & 240 & 240 & 80 & 80 & 80 & 80 \\
\hline $\mathrm{CO}$ & 600 & 600 & 600 & 600 & 600 & 600 & 600 & 600 & 600 & 600 & 600 & 600 & 600 & 600 & 600 \\
\hline Bidirectional VOC & 500 & 500 & 500 & 500 & 500 & 500 & 500 & 500 & 500 & 500 & 500 & 80 & 80 & 80 & 80 \\
\hline Stress VOC & 300 & 300 & 300 & 300 & 300 & 300 & 300 & 300 & 300 & 300 & 300 & 300 & 300 & 300 & 300 \\
\hline Other VOC & 140 & 140 & 140 & 140 & 140 & 140 & 140 & 140 & 140 & 140 & 140 & 140 & 140 & 140 & 140 \\
\hline
\end{tabular}

needs for local (i.e. site specific), regional (which may include detailed vegetation species composition data) and global modeling. This enabled users to customize vegetation emission type schemes ranging from detailed (e.g. individual plant species or even sub species) to generic (e.g. a few broad vegetation categories). MEGAN2.1 emission factors can be specified from gridded maps based on species composition and species-specific emission factors or by using plant functional type (PFT) distributions and the PFT specific emission factors listed in Table 2. The MEGAN2.1 PFT scheme, shown in Table 3, adopts the scheme used for CLM4 (Lawrence et al., 2011).

The previous version, MEGAN2.0, defined emission factors as the net flux of a compound into the atmosphere. This was intended to account for losses of primary emissions on their way into the above canopy atmosphere. For example, some of the isoprene emitted from leaves into the canopy airspace does not escape into the above canopy atmosphere but is consumed on canopy and soil surfaces or reacts within the canopy airspace. The MEGAN2.1 emission factor represents the net primary emission that escapes into the atmosphere but is not the net flux because it does not include the flux of chemicals from the above canopy atmosphere down into the canopy. Emission factors based on scaled up leaf level emissions inherently exclude the deposition component. In order to use above canopy flux measurements to establish emission factors, an estimate of the deposition flux is added to the above canopy flux measurements to determine the MEGAN2.1 emission factors. For example, for a net methanol flux of $800 \mu \mathrm{g} \mathrm{m}^{-2} \mathrm{~h}^{-1}$ measured above a forest canopy and an estimate of methanol dry deposition flux of $100 \mu \mathrm{g} \mathrm{m}^{-2} \mathrm{~h}^{-1}$, the net primary emission used for the MEGAN2.1 emission factor would be $900 \mu \mathrm{g} \mathrm{m}^{-2} \mathrm{~h}^{-1}$. For isoprene and other terpenoid compounds, this adjustment is a few percent or less.

The ability of plants to emit a specific chemical species can be widespread, occurring in all or most plants, or limited, occurring in a select group of plants. Isoprene is an example of a compound with a limited distribution in the plant kingdom while many other VOC are emitted from most plants. A vegetation emission type scheme for a compound with a limited distribution in the plant kingdom, such as isoprene, should distinguish between emitters and nonemitters. The scheme must also consider that isoprene emitting plants do not all have the same emission factor. This has led to the compilation of lists assigning specific emission factors to individual plant species. For example, Benjamin et al. (1996) has compiled a list that indicates that there are large differences in the isoprene emission factors for isoprene emitting broadleaf trees in North America including Nyssa sylvatica, Platanus occidentalis, Robinia pseudoacacia, and North American Populus, Salix, and Quercus species. However, Geron et al. (2000) conducted a survey of leaf level emissions of these species and found that the within-species variations in isoprene emissions are about the same as the between-species variations. The Benjamin et al. (1996) values for isoprene emission factors range over more than an order of magnitude for $Q$. lobata, Q. alba, Q. phellos, Salix nigra, and Populus deltoides while the Geron at al. (2000) measurements using a consistent measurement technique indicate that the emission factors for these species vary by less than $10 \%$. The Geron et al. (2000) result demonstrates that it is reasonable to define a limited number of isoprene emission factor types. The 16 CLM4 PFTs are similar, or even more detailed, to those used for other global land surface models but are not sufficient for describing the observed variability in isoprene emission factors. For example, the "Broadleaf 
Table 3. CLM4 global land area $\left(10^{12} \mathrm{~km}^{2}\right.$ ) and isoprene, monoterpene (MT) and other (VOC and CO) emissions for individual plant functional types estimated using MEGAN2.1 algorithms in CLM4 for year 2000.

\begin{tabular}{rlrrrr}
\hline $\begin{array}{r}\text { CLM PFT } \\
\text { Number }\end{array}$ & Description & $\begin{array}{r}\text { Land } \\
\text { Area }\end{array}$ & $\begin{array}{r}\text { Isoprene } \\
\mathrm{Tg} \mathrm{yr}^{-1}\end{array}$ & $\begin{array}{r}\text { MT } \\
\mathrm{Tg} \mathrm{yr}^{-1}\end{array}$ & $\begin{array}{r}\text { Other } \\
\mathrm{Tg} \mathrm{yr}^{-1}\end{array}$ \\
\hline & Bare & 40.7 & & & \\
1 & Needleleaf Evergreen Temperate Tree & 5.46 & 1.61 & 7.38 & 13.2 \\
2 & Needleleaf Evergreen Boreal Tree & 10.6 & 5.9 & 6.63 & 9.52 \\
3 & Needleleaf Deciduous Boreal Tree & 1.46 & 0.0002 & 0.52 & 0.89 \\
4 & Broadleaf Evergreen Tropical Tree & 15.6 & 244 & 82.9 & 127 \\
5 & Broadleaf Evergreen Temperate Tree & 2.64 & 21.9 & 4.0 & 8.71 \\
6 & Broadleaf Deciduous Tropical Tree & 12.9 & 178 & 45.0 & 74.3 \\
7 & Broadleaf Deciduous Temperate Tree & 5.33 & 35.4 & 5.86 & 13.1 \\
8 & Broadleaf Deciduous Boreal Tree & 2.14 & 4.79 & 0.99 & 2.02 \\
9 & Broadleaf Evergreen Temperate Shrub & 0.18 & 0.23 & 0.08 & 0.33 \\
10 & Broadleaf Deciduous Temperate Shrub & 4.15 & 21.8 & 6.77 & 16.4 \\
11 & Broadleaf Deciduous Boreal Shrub & 9.33 & 2.93 & 1.07 & 3.3 \\
12 & Arctic C3 Grass & 4.94 & 0.97 & 0.02 & 1.45 \\
13 & Cool C3 Grass & 14.3 & 11.2 & 0.25 & 26.1 \\
14 & Warm C4 Grass & 13.2 & 5.93 & 0.49 & 51.3 \\
15 & Crop1 & 16.3 & 0.02 & 0.36 & 44.5 \\
\hline & Total (all PFTs) & 159 & 535 & 162 & 390 \\
\hline
\end{tabular}

Deciduous Temperate Tree" category includes maple (Acer) trees that have negligible isoprene emissions and oak (Quercus) trees that emit at high rates. For other PFTs, such as "Needleleaf Deciduous Boreal Tree" with only negligible isoprene emitters, the CLM4 scheme is sufficient. To account for this variability, the base MEGAN2.1 land cover includes more than 2000 ecoregions which allows the PFT emission factors to differ in each region. The PFT emission factors for ecoregions in the US, Europe, Australia and some other regions are based on the combination of species composition data and species specific emission factors while the PFT emission factors for ecoregions in tropical forests and some other regions are directly based on above canopy flux measurements. The global average PFT emission factors shown in Table 2 are the area weighted average of all ecoregions.

\subsection{Emission activity algorithms}

MEGAN emissions are based on a simple mechanistic model that considers the major processes driving variations in emissions. For light dependent emissions, this includes a light response that is based on electron transport (Guenther et al., 1991), a temperature response based on enzymatic activity (Guenther et al., 1991), and a $\mathrm{CO}_{2}$ response based on changes in metabolite pools, enzyme activity and gene expression (Wilkinson et al., 2009). The activity factor for each compound class $\left(\gamma_{i}\right)$ accounts for emission response to light $\left(\gamma_{\mathrm{P}}\right)$, temperature $\left(\gamma_{\mathrm{T}}\right)$, leaf age $\left(\gamma_{\mathrm{A}}\right)$, soil moisture $\left(\gamma_{\mathrm{SM}}\right)$, leaf area index (LAI) and $\mathrm{CO}_{2}$ inhibition $\left(\gamma_{\mathrm{C}}\right)$ as

$\gamma_{i}=C_{\mathrm{CE}} \mathrm{LAI} \gamma_{\mathrm{P}, i} \gamma_{\mathrm{T}, i} \gamma_{\mathrm{A}, i} \gamma_{\mathrm{SM}, i} \gamma_{\mathrm{C}, i}$
The canopy environment coefficient $\left(C_{\mathrm{CE}}\right)$ is assigned a value that results in $\gamma=1$ for the standard conditions and is dependent on the canopy environment model being used. For example, a value of 0.30 is used for CLM4 canopy environment model and a value of 0.57 is used for the MEGAN2.1 WRF-AQ canopy environment model.

Emissions of each compound class include a lightdependent fraction (LDF, shown in Table 4) with the remaining light independent fraction (LIF $=1-\mathrm{LDF}$ ) that is not influenced by light. The emission activity factor accounting for the light response of emissions is estimated as

$\gamma_{\mathrm{P}, i}=\left(1-\mathrm{LDF}_{i}\right)+\mathrm{LDF}_{i} \gamma_{\mathrm{P} \_\mathrm{LDF}}$

where $\gamma_{\mathrm{PLDF}}$ follows the light-dependent activity factor described for isoprene by Guenther et al. (2006) as

$\gamma_{\mathrm{P} \_L D F}=C_{\mathrm{P}}\left[(\alpha \times\right.$ PPFD $\left.) /\left(\left(1+\alpha^{2} \times \mathrm{PPFD}^{2}\right)^{0.5}\right)\right]$

where PPFD is the photosynthetic photon flux density $\left(\mu \mathrm{mol} \mathrm{m}{ }^{-2} \mathrm{~s}^{-1}\right.$ ) and $C_{\mathrm{P}}$ and $\alpha$ are estimated as

$$
\begin{aligned}
\alpha & =0.004-0.0005 \ln \left(P_{240}\right) \\
C_{\mathrm{P}} & =0.0468 \times \exp \left(0.0005 \times\left[P_{24}-P_{\mathrm{S}}\right]\right) \times\left[P_{240}\right]^{0.6}
\end{aligned}
$$

where $P_{\mathrm{S}}$ represents the standard conditions for PPFD averaged over the past $24 \mathrm{~h}$ and is equal to $200 \mu \mathrm{mol} \mathrm{m}^{-2} \mathrm{~s}^{-1}$ for sun leaves and $50 \mu \mathrm{mol} \mathrm{m} \mathrm{m}^{-2} \mathrm{~s}^{-1}$ for shade leaves, $P_{24}$ is the average PPFD of the past $24 \mathrm{~h}$ and $P_{240}$ is the average PPFD of the past $240 \mathrm{~h}$. The light response is applied separately for the sunlit and shaded leaves at each canopy depth using PPFD estimated using a canopy environment model (see Sect. 2.4.1). 
Table 4. MEGAN2.1 model parameters.

\begin{tabular}{lrrrrrrrr}
\hline Compound Class & $\beta$ & LDF & $C_{t 1}$ & $C_{\text {eo }}$ & $A_{\text {new }}$ & $A_{\text {gro }}$ & $A_{\text {mat }}$ & $A_{\text {old }}$ \\
\hline Isoprene & 0.13 & 1 & 95 & 2 & 0.05 & 0.6 & 1 & 0.9 \\
Myrcene & 0.1 & 0.6 & 80 & 1.83 & 2 & 1.8 & 1 & 1.05 \\
Sabinene & 0.1 & 0.6 & 80 & 1.83 & 2 & 1.8 & 1 & 1.05 \\
Limonene & 0.1 & 0.2 & 80 & 1.83 & 2 & 1.8 & 1 & 1.05 \\
3-Carene & 0.1 & 0.2 & 80 & 1.83 & 2 & 1.8 & 1 & 1.05 \\
$t$ - $\beta$-Ocimene & 0.1 & 0.8 & 80 & 1.83 & 2 & 1.8 & 1 & 1.05 \\
$\beta$-Pinene & 0.1 & 0.2 & 80 & 1.83 & 2 & 1.8 & 1 & 1.05 \\
$\alpha$-Pinene & 0.1 & 0.6 & 80 & 1.83 & 2 & 1.8 & 1 & 1.05 \\
Other Monoterpenes & 0.1 & 0.4 & 80 & 1.83 & 2 & 1.8 & 1 & 1.05 \\
$\alpha$-Farnesene & 0.17 & 0.5 & 130 & 2.37 & 0.4 & 0.6 & 1 & 0.95 \\
$\beta$-Caryophyllene & 0.17 & 0.5 & 130 & 2.37 & 0.4 & 0.6 & 1 & 0.95 \\
Other Sesquiterpenes & 0.17 & 0.5 & 130 & 2.37 & 0.4 & 0.6 & 1 & 0.95 \\
232-MBO & 0.13 & 1 & 95 & 2 & 0.05 & 0.6 & 1 & 0.9 \\
Methanol & 0.08 & 0.8 & 60 & 1.6 & 3.5 & 3 & 1 & 1.2 \\
Acetone & 0.1 & 0.2 & 80 & 1.83 & 1 & 1 & 1 & 1 \\
CO & 0.08 & 1 & 60 & 1.6 & 1 & 1 & 1 & 1 \\
Bidirectional VOC & 0.13 & 0.8 & 95 & 2 & 1 & 1 & 1 & 1 \\
Stress VOC & 0.1 & 0.8 & 80 & 1.83 & 1 & 1 & 1 & 1 \\
Other VOC & 0.1 & 0.2 & 80 & 1.83 & 1 & 1 & 1 & 1 \\
\hline
\end{tabular}

The temperature activity factor is also the weighted average of a light-dependent and light-independent fraction

$\gamma_{\mathrm{T}, i}=\left(1-\mathrm{LDF}_{i}\right) \gamma_{\mathrm{T} L \mathrm{LIF}, \mathrm{i}}+\mathrm{LDF}_{i} \gamma_{\mathrm{T} L \mathrm{LDF}, i}$.

The light-dependent fraction response is calculated following the isoprene-response described by Guenther et al. (2006):

$$
\begin{array}{r}
\gamma_{\mathrm{T} \_\mathrm{LDF}, i}=E_{\mathrm{opt}} \times\left[C_{T 2} \times \exp \left(C_{T 1, i} \times x\right)\right. \\
\left./\left(C_{T 2}-C_{T 1, i} \times\left(1-\exp \left(C_{T 2} \times x\right)\right)\right)\right]
\end{array}
$$

where $x=\left[\left(1 / T_{\mathrm{opt}}\right)-(1 / T)\right] / 0.00831, T$ is leaf temperature (K), $C_{T 1, i}$ (see Table 4 for emission class dependent values) and $C_{T 2}(=230)$ are empirically determined coefficients,

$$
\begin{aligned}
T_{\mathrm{opt}} & =313+\left(0.6 \times\left(T_{240}-T_{\mathrm{s}}\right)\right) \\
E_{\mathrm{opt}} & =C_{\mathrm{eo}, i} \times \exp \left(0.05 \times\left(T_{24}-T_{\mathrm{s}}\right)\right) \\
& \times \exp \left(0.05 \times\left(T_{240}-T_{\mathrm{s}}\right)\right)
\end{aligned}
$$

where $T_{\mathrm{S}}$ represents the standard conditions for leaf temperature $(=297 \mathrm{~K}), T_{24}$ is the average leaf temperature of the past $24 \mathrm{~h}, T_{240}$ is the average leaf temperature of the past $240 \mathrm{~h}$, and $C_{\mathrm{eo}, i}$ is an emission-class dependent empirical coefficient (see Table 4). The response of the light-independent fraction follows the monoterpene exponential temperature response function of Guenther et al. (1993)

$\gamma_{\mathrm{T} \_ \text {LIF }, i}=\exp \left(\beta_{i}\left(T-T_{\mathrm{s}}\right)\right)$

where $\beta_{i}$ is an empirically determined coefficient shown in Table 4 for each emission class.
The leaf age emission activity factor is estimated as

$$
\begin{aligned}
\gamma_{\mathrm{A}, i} & =F_{\text {new }} \times A_{\text {new }, i}+F_{\text {gro }} \times A_{\text {gro }, i}+F_{\text {mat }} \\
& \times A_{\text {mat }, i}+F_{\text {sen }} \times A_{\text {sen }, i}
\end{aligned}
$$

where $A_{\text {new }, i}, A_{\text {gro }, i}, A_{\text {mat }, i}$, and $A_{\text {sen, } i}$ are empirical coefficients, shown in Table 4 , that describe the relative emission rates for new, growing, mature, and senescing leaves, respectively. Table 4 shows that new leaves are predicted to have $5 \%$ of the isoprene emission rate, but a factor of 3.5 higher methanol emission rate, in comparison to mature leaves. Monoterpene emissions are predicted to decline with age while sesquiterpene emissions are predicted to increase. The MEGAN model for estimating leaf age fractions, described in Sect. 2.4, divides the canopy into four fractions: new foliage $\left(F_{\text {new }}\right)$, growing (expanding) foliage $\left(F_{\text {gro }}\right)$, mature foliage $\left(F_{\text {mat }}\right)$ and senescing foliage $\left(F_{\text {sen }}\right)$.

The MEGAN soil moisture dependence algorithm (Guenther et al., 2006) for isoprene emission is estimated as

$$
\begin{array}{ll}
\gamma_{\mathrm{SM}, \text { isoprene }}=1 & \theta>\theta_{1} \\
\gamma_{\mathrm{SM}, \text { isoprene }}=\left(\theta-\theta_{\mathrm{w}}\right) / \Delta \theta_{1} & \theta_{\mathrm{w}}<\theta<\theta_{1} \\
\gamma_{\mathrm{SM}, \text { isoprene }}=0 & \theta<\theta_{\mathrm{w}}
\end{array}
$$

where $\theta$ is soil moisture (volumetric water content, $\mathrm{m}^{3} \mathrm{~m}^{-3}$ ), $\theta_{\mathrm{W}}$ is wilting point (the soil moisture level below which plants cannot extract water from soil, $\left.\mathrm{m}^{3} \mathrm{~m}^{-3}\right), \Delta \theta_{1}(=0.04)$ is an empirical parameter and $\theta_{1}$ is defined as $\theta_{\mathrm{w}}+\Delta \theta_{1}$. Estimates of $\theta$ and $\theta_{\mathrm{w}}$ are provided by weather models (Sect. 3.3.3). Equation (13) is used only to estimate emissions of isoprene. All other compounds are assigned a value of $\gamma_{\mathrm{SM}, i}=1$. 
The isoprene emission activity factor associated with the $\mathrm{CO}_{2}$ inhibition follows Heald et al. (2009)

$\gamma_{\mathrm{CO}_{2}, \text { isoprene }}=I_{\text {Smax }}-\left[\left(I_{\text {Smax }}\left(C_{i}\right)^{h}\right) /\left((C *)^{h}+\left(C_{i}\right)^{h}\right)\right]$

where $I_{\mathrm{Smax}}, C *$, and $h$ are empirically determined coefficients and the internal $\mathrm{CO}_{2}$ concentration, $C_{i}$, is estimated as $70 \%$ of the ambient $\mathrm{CO}_{2}$ concentration. Equation 14 is used only to estimate emissions of isoprene. All other compounds are assigned a value of $\gamma_{\mathrm{CO}_{2}, i}=1$.

\subsection{Model parameters}

The isoprene measurements used to develop the MEGAN2.1 emission factors and emission algorithm parameterizations are described by Guenther et al. (2006) and Heald et al. (2009). Most of the dominant tree genera and species in temperate and boreal forests have been characterized at least to the level of emitter or non-emitter and this information was combined with tree inventories to estimate ecoregion average isoprene emission capacities for individual plant functional types (PFTs). Tropical forest isoprene emission factors are based primarily on above canopy measurements due to the high species diversity.

The starting point for the MEGAN2.1 monoterpene emission factors and algorithms is the global database of Guenther et al. (1995). These observations have been supplemented with results summarized for North America (Guenther et al., 2000; Geron et al., 2000; Sakulyanontvittaya et al., 2008), South America (Greenberg et al., 2004; Karl et al., 2007), Europe (Karl et al., 2009), Africa (Guenther et al., 1999; Otter et al., 2003) and Asia (Klinger et al., 2002; Tie et al., 2006). These studies indicate that the value of $\beta$, which determines the temperature response of monoterpene emissions, is slightly higher than the value of 0.09 recommended by Guenther et al. (1993) and a value of 0.1 is used (Table 4) for monoterpenes in MEGAN2.1.

Sesquiterpene emissions have been detected from numerous plant species including conifer and broadleaf trees, shrubs, and agricultural crops. Duhl et al. (2008) reviewed laboratory and field studies of leaf age, light and temperature controls over sesquiterpene emissions, and recommended emission factors for major vegetation types although they also noted a large variability within each type. The sesquiterpene emission factors and emission algorithm parameterizations used for MEGAN2.1 are based on the measurements summarized by Duhl et al. (2008).

The production and emission of the hemiterpene alcohols, methylbutenols, by insects and flowers has been known for many years. Two of these compounds, 3-methyl-2-buten-1ol and 3-methyl-3-buten-1-ol, have been observed as minor components of ecosystem BVOC emissions and are grouped with the other BVOC category. A third compound, 2-methyl3-buten-2-ol (referred to here as MBO) is of greater importance. It was identified as an important atmospheric BVOC in a Rocky Mountain subalpine forest by Goldan et al. (1993).
It is a major emission for some, but not all, Pinus (pine tree) species (Harley et al., 1998) and so is a dominant BVOC emission in many western North America forests but is only a minor component of global emissions. MBO is emitted by both European bark beetles and North American pine trees but is not emitted in substantial amounts by either European pines or North American bark beetles. The MEGAN2.1 emission factors for temperate conifers and the response to light and temperature are based on enclosure and above canopy flux measurements (Harley et al., 1998; Schade et al., 2000; Baker et al., 2001; Karl et al., 2002; Gray et al., 2005; and Kim et al., 2010). The boreal emission factors are based on the measurements of Tarvainen et al. (2005).

The MEGAN2.1 methanol emission factors and algorithms, and the observations they are based on, have been described and evaluated with comparison to satellite and aircraft observations by Stavrakou et al. (2011). Enclosure (MacDonald and Fall, 1993b; Janson et al., 1999) and above canopy eddy flux (Karl et al., 2002, 2004; Baker et al., 1999; Schade and Goldstein, 2001) studies have been used to establish the MEGAN2.1 acetone emission factors and response to light and temperature. The parameterizations of carbon monoxide (CO) emissions are based on relatively few observations described by Tarr et al. (1995).

The strong bidirectional exchange exhibited by acetaldehyde, formaldehyde, acetic acid, and formic acid requires their inclusion in a separate MEGAN2.1 category. Accurate simulation of land-atmosphere fluxes of these compounds requires estimates of their atmospheric concentrations and the compensation point for each compound. As an intermediate step, MEGAN2.1 uses a simple approach with the acetaldehyde and ethanol emission factors and algorithms described by Millet et al. (2010). Emission factors for formic and acetic acid are based on enclosure measurements reported by Kesselmeier et al. (1997), Kreuzwieser et al. (1999), Martin et al. (1999) and Kesselmeier (2001) which suggest that emissions of these compounds are small, although with a large uncertainty.

Sawada and Totsuka (1986) extrapolated enclosure measurements showing widespread ethene production by plants in most landscapes. Canopy scale fluxes measured by Goldstein et al. (1996) above a temperate deciduous forest confirmed that substantial amounts of ethene were released into the atmosphere from this landscape. The Goldstein et al., canopy scale fluxes agree reasonably well with the Sawada and Totsuka enclosure measurements and are used as the basis for the MEGAN2.1 parameterization of ethene emissions.

Niinemets (2010) recently reviewed the environmental and biotic stresses that can substantially modify emission rates of biogenic VOC and concluded that a quantitative understanding of stress effects was needed in order to accurately represent these emissions in numerical models. Stress tolerance, timing, duration, and severity were identified as the key factors controlling emissions variations in response to stress. In order to highlight BVOC that are especially sensitive to 
stress, MEGAN2.1 includes fifteen compounds in a stress emission category (Table 1). In addition, a monoterpene (ocimene) and a sesquiterpene (farnesene) that are highly sensitive to induced stress are assigned their own categories. The current limited knowledge precludes a quantitative treatment of emission variations due to stress and so the current estimates of these compounds are highly uncertain. The resulting estimates provide a first step towards assessing the importance of these BVOC emissions though additional measurements are needed. Elevated emissions of green leaf volatiles (e.g., cis-3-hexenal, trans-2-hexenal, hexanal, 1-hexanol and cis-3-hexenol), monoterpenes (e.g. ocimene), sesquiterpenes (e.g. farnesene), homoterpenes including dimethyl-nonatriene (DMNT) and trimethyltridecatetraene (TMTT), aromatics (e.g. toluene, indole, methyl salicylate), and jasmonates (methyl jasmonate and jasmone) are among the most important compounds observed in response to plant stress (Poulton, 1990; Heiden et al., 1999; Engelberth et al., 2004; Turlings and Ton, 2006; Niinemets, 2010). Due to the importance of these emissions for plantherbivore and plant-pathogen interactions, there have been many investigations of the biochemical pathways and the roles of these emissions in plant defense (Kant et al., 2009). In comparison, there are few observations suitable for incorporating into emission models.

Warneke et al. (2002) quantified above-canopy fluxes of methanol and cis-3-hexenal from an undisturbed alfalfa field in Colorado. Emissions of the two compounds were greatly increased during harvesting and continued to emit at high rates as the alfalfa was drying. In addition, fluxes of hexenylacetate, 1-hexenol, hexanal, and butanone were observed during harvesting. Similar results have been observed with lawn mowing and hay harvesting resulting in emissions that dominate total fluxes from some regions during periods of harvesting (Karl et al., 2001). In addition to the Warneke et al. (2002) and Karl et al. (2001) eddy flux studies, the MEGAN2.1 parameters for these compounds are based on the enclosure measurements of König et al. (1994) and Kirstine et al. (1998). Karl et al. (2008) used the eddy covariance technique to quantify canopy scale fluxes of methyl salicylate from a walnut plantation and observed a strong correlation with both temperature and water stresses. Heiden et al. (1999) used enclosure techniques to characterize toluene emissions from stressed and unstressed plants. Shim et al. (2007) used inverse modeling to estimate global average biogenic emissions of hydrogen cyanide which is emitted from thousands of plant species, including many economically important food plants, when they are wounded.

Matsunaga et al. (2008) observed significant emissions of the "sunscreen" compounds, homosalate $\left(\mathrm{C}_{16} \mathrm{H}_{22} \mathrm{O}_{3}\right)$ and 2-ethylhexyl salicylate [also known as octyl salate] $\left(\mathrm{C}_{15} \mathrm{H}_{22} \mathrm{O}_{3}\right)$, from Mojave desert plants and much lower emissions from temperate forest tree species. They were the major BVOC emission observed from mesquite (Prosopis spp.) which dominates large areas in the southwestern US.
These photoprotective plant wax components are used in commercial sunscreens and protect plant tissues by absorbing harmful UV solar radiation. The oxidation of plant waxes by ozone and other atmospheric oxidants produces volatile and semi-volatile products that are emitted into the atmosphere. For example, Fruekilde et al. (1998) observed significant emissions of geranyl acetone $\left(\mathrm{C}_{13} \mathrm{H}_{22} \mathrm{O}\right)$, 4-oxopentanal $\left(\mathrm{C}_{5} \mathrm{H}_{8} \mathrm{O}_{2}\right)$ and methyl heptenone when leaf surfaces were exposed to high levels of ozone.

MEGAN2.1 organic halide emissions include methyl bromide, methyl chloride and methyl iodide. Quantifying the impact of terrestrial ecosystems on atmospheric organic halides is complicated by the presence of both sources and sinks but they are thought to be a net global source (Rhew et al., 2000; Yoshida et al., 2006; Sive et al., 2007). Terrestrial emissions of these compounds follow diurnal and seasonal variations similar to those observed for other trace gases with higher emissions during the growing season (Rhew et al., 2000).

Sulfur compounds are produced in both soils and vegetation in terrestrial ecosystems and emitted into the atmosphere at rates that are low compared to anthropogenic sulfur emissions but can be significant in pristine regions (Bates et al., 1992). MEGAN2.1 emission factors and parameterizations for carbon disulfide, carbonyl sulfide, hydrogen sulfide, methyl mercapten, dimethyl sulfide and dimethyl disulfide are based on the values recommended by Watts (2000). Measurements of diallyl disulfide, methyl propenyl disulfide, propenylpropyldisulfide reported by Puxbaum and König (1997) are the basis of the MEGAN2.1 values for these compounds.

MEGAN2.1 includes contributions from other alkenes including propene and butene emissions which were quantified with above canopy flux measurements by Goldstein et al. (1996). Emissions of larger alkenes (1-dodecene, 1-tetradecene) have been quantified using enclosure measurements (Arey et al., 1991). In addition to the 232methylbutenol discussed in Sect. 2.1.3, other methylbutenols include prenol, (321-MBO) an important flavour and fragrance compound, and 331-MBO, an aggregation pheromone of bark beetles, e.g. Ips cembrae, (Stoakley et al., 1978).

1,3-octenol provides the characteristic odor of mushrooms and has been quantified in emissions from Fescue (Tava et al., 1995). Neryl acetone (Helmig et al., 2006), terpinyl acetate (Yani et al., 1993) and nonenal (Helmig et al., 1999) have also been observed using enclosure measurement techniques.

Alkanes emitted from terrestrial ecosystems include ethane (Burr et al., 1991; Kirstine et al., 1998), propane (Janson et al., 1999), pentane (Isidorov, 1985), hexane (Owen et al., 1997) and heptane (Savage et al., 1996). Although the rates reported by these investigators are typically negligible in urban areas in comparison to anthropogenic emissions, they are included in MEGAN2.1 to recognize that there are biogenic sources of these compounds. The MEGAN2.1 
parameters for saturated aldehydes (hexanal, heptanal, octanal, nonanal, and decanal) are based on the measurements reported by Wildt et al. (2003). Other MEGAN2.1 unsaturated oxygenated VOC include octanol (Tava et al., 1995), heptanone (Connick et al., 1989), 2-butanone (Kirstine et al., 1998; Warneke et al., 2002), and pyruvic acid (Talbot et al., 1990).

A variety of benzenoid compounds (e.g. aromatics) are produced by plants for signaling (e.g. attract pollinators with floral scents) and defense (Dudareva et al., 2006). These include compounds such as toluene and methyl salicylate that are included with the stress compounds. Many other benzenoids are well known as components of floral scents, in addition to being stress compounds, and selected benzenoids have been included in MEGAN2.1 to represent this large class of compounds. This includes benzaldehyde, methyl benzoate, 2-phenylacetaldehyde, eugenol, benzyl acetate, benzyl alcohol, and naphthalene for which MEGAN2.1 parameters are based on emission rates reported by Tava et al., 1995; Kirstine et al., 1998; Turlings et al., 1998; Kolosova et al., 2001; Krauss et al., 2005; Knudsen et al., 2006; and Baghi et al., 2012.

\subsection{Intermediate models for processing driving variables}

\subsubsection{Canopy environment}

Light and temperature vary dramatically within a vegetation canopy resulting in much lower emissions of light dependent BVOC, such as isoprene, in shaded portions of a canopy. MEGAN2.1 calculates leaf temperature instead of assuming that leaf temperature is equal to ambient temperature which typically results in small $(<5 \%)$ underestimates in emissions. MEGAN2.1 canopy scale emission factors provide the same emission at standard conditions regardless of the canopy environment model being used. Keenan et al. (2011) show that different canopy environment models result in very different emissions, even at the standard conditions, when using leaf level emission factors. However, they also show that the different canopy environment models have considerably different isoprene emission responses to changes in environmental conditions. A better understanding of canopy environment processes is needed to improve biogenic emission estimates. Field observations of emissions and light and temperature variations throughout canopies are needed to accomplish this.

\subsubsection{Above canopy environment}

Solar radiation directly influences emissions of some BVOC and indirectly influences emissions of other BVOC through leaf temperature. The algorithms used for calculating solar radiation at the top of a canopy and for solar decomposition (direct and diffuse light components as well as visi- ble and near-infrared components) vary considerably and, as described in this section, there is a substantial range in the values estimated by different techniques.

MEGAN results are sensitive to uncertainties in the approaches used to decompose solar radiation into direct visible, diffuse visible, direct infrared, and diffuse infrared components. Algorithms for estimating diffuse visible fraction are uncertain which can have a substantial impact on isoprene emission estimates. This is because direct light only influences sun leaves, which tend to already be light saturated, while diffuse light is important for shade leaves that often have a nearly linear increase in isoprene emission with light. For example, we used BEIS3.14 (based on Pierce et al., 1998), MEGAN 2.0 (Guenther et al., 2006) and the WRFAQ version of MEGAN 2.1 to estimate above canopy diffuse PPFD for a two week period in July 2010 in Boulder CO USA and found that the midday values differed by about $30 \%$ and the morning and evening values by an even greater amount.

Another important issue is the conversion of solar radiation in $\mathrm{W} \mathrm{m}^{-2}$ to Photosynthetic Photon Flux Density (PPFD) in units of $\mu$ mol photons $\mathrm{m}^{-2} \mathrm{~s}^{-1}$. PPFD is the flux of photons in the 400 to $700 \mathrm{~nm}$ spectral range of solar radiation that photosynthetic organisms are able to use in the process of photosynthesis. BEIS3.14 and MEGAN2.02 used values of 4.6 and $4.55 \mu \mathrm{mol}$ photons per Joule, respectively. The WRF-AQ version of MEGAN2.1 uses different conversion factors for direct $(4.0 \mu \mathrm{mol}$ photons per Joule) and diffuse light ( $4.6 \mu \mathrm{mol}$ photons per Joule) based on observations reported by Lizaso et al. (2005) and Jacovides et al. (2007).

\subsection{Driving variables}

MEGAN2.1 is driven by driving variables that include meteorology (e.g., hourly temperature, solar radiation, humidity, wind speed and soil moisture), and land cover data including LAI and PFT fractions. $\mathrm{CO}_{2}$ concentrations can be gridded inputs from a coupled atmospheric model (e.g., CESM) or user specified values. Biogenic emission model sensitivity studies summarized in Table 5 show that the use of different driving variables can result in large differences in global BVOC emission estimates. For example, Guenther et al. (2006) report differences in MEGAN2.0 annual isoprene emissions as a result of changing PFT (24\%), LAI (29\%) and meteorology (15\%) input data. Pfister et al. (2008) used three different PFT and LAI databases to drive MEGAN2.0 and found global differences of about $30 \%$ and regional differences exceeding $60 \%$. Arneth et al. (2011) compared MEGAN2.0 with two other global isoprene emission models and found that the models broadly agree when driven with the same input data and that differences of more than $30 \%$ were associated with changes in driving variables. Differences in model algorithms made a relatively small difference in global emission totals. An interesting finding from the Arneth et al. (2011) model comparison is that changing 
Table 5. Comparison of global annual emissions estimates $\left(\mathrm{Tg}^{-1}\right)$.

\begin{tabular}{|c|c|c|c|c|c|c|}
\hline Model & Weather & LAI & PFT & $\mathrm{EF}$ & Emissions & Reference \\
\hline \multicolumn{7}{|l|}{ Global isoprene emission } \\
\hline CLM-MEGAN2.1 & Qian 2006 & CLM4-SP & CLM4 & MEGAN2.1 map & 535 & This study \\
\hline CLM-MEGAN2.1 & Qian 2006 & CLM4-SP & CLM4 & MEGAN2.1 PFT & 529 & This study \\
\hline CLM-MEGAN2.1 & Qian 2006 & CLM4-CN & CLM4 & MEGAN2.1 PFT & 578 & This study \\
\hline G95 & IIASA & GVI & Olson (1992) & G95 & 568 & Guenther et al. (1995) \\
\hline MEGAN2.0 & HadCM2 & MEGAN2 & MEGAN2 & MEGAN2 & 713 & Guenther et al. (2006) \\
\hline MEGAN2.0 & MM5 & MEGAN2 & MEGAN2 & MEGAN2 & 533 & Guenther et al. (2006) \\
\hline MEGAN2.0 & NCEP & MEGAN2 & MEGAN2 & MEGAN2 & 620 & Guenther et al. (2006) \\
\hline MEGAN2.0 & NCEP & MAPSS-L & MEGAN2 & MEGAN2 & 800 & Guenther et al. (2006) \\
\hline MEGAN2.0 & NCEP & AVHRR1-L & MEGAN2 & MEGAN2 & 552 & Guenther et al. (2006) \\
\hline MEGAN2.0 & NCEP & MEGAN2 & MAPPS-P & MEGAN2 & 769 & Guenther et al. (2006) \\
\hline MEGAN2.0 & NCEP & MEGAN2 & HYDE & MEGAN2 & 539 & Guenther et al. (2006) \\
\hline MEGAN2.0 & NCEP & MODIS-L & MODIS-L & MEGAN2 & 531 & Pfister et al. (2008) \\
\hline MEGAN2.0 & NCEP & MODIS-T & MODIS-T & MEGAN2 & 678 & Pfister et al. (2008) \\
\hline MEGAN2.0 & NCEP & CLM & CLM & MEGAN2 & 350 & Pfister et al. (2008) \\
\hline LPJ-GUESS & CRU & LPJV & LPJV & LPJ-GUESS & 523 & Arneth et al. (2011) \\
\hline BVOCEM & UM & BVOCEM & BVOCEM & BVOCEM & 560 & Arneth et al. (2011) \\
\hline \multicolumn{7}{|c|}{ Total monoterpene emission } \\
\hline CLM-MEGAN2.1 & Qian 2006 & CLM4-SP & CLM4 & PFT average & 157 & This study \\
\hline CLM-MEGAN2.1 & Qian 2006 & CLM4-CN & CLM4 & PFT average & 177 & This study \\
\hline LPJ-GUESS-a1 & CRU & LPJV & LPJV & LPJ-GUESS & 30 & Schurgers et al. (2009) \\
\hline LPJ-GUESS-a2 & CRU & LPJV & LPJV & LPJ-GUESS & 32 & Schurgers et al. (2009) \\
\hline G95 & IIASA & GVI & Olson (1992) & G95 & 144 & Guenther et al. (1995) \\
\hline \multicolumn{7}{|l|}{$\beta$-pinene emission } \\
\hline CLM-MEGAN2.1 & Qian (2006) & CLM4-CN & CLM4 & PFT average & 24 & This study \\
\hline CLM-MEGAN2.1 & Qian (2006) & CLM4-SP & CLM4 & PFT average & 19 & This study \\
\hline \multicolumn{7}{|l|}{ Methanol emission } \\
\hline CLM-MEGAN2.1 & Qian 2006 & CLM4-SP & CLM4 & PFT average & 99 & This study \\
\hline IMAGES-MEGAN2.1 & ERA & MODIS & MODIS & PFT average & 105 & Stavrakou et al. (2011) \\
\hline GEOS-MEGAN2 & GEOS & GEOS & GEOS & PFT average & 151 & Jacob et al. (2002) \\
\hline GEOS-MEGAN2 & GEOS & GEOS & GEOS & PFT average & 103 & Millet et al. (2008) \\
\hline GK02 & GK02 & GK02 & GK02 & GK02 & 100 & Galbally and Kirstine (2002) \\
\hline \multicolumn{7}{|l|}{ Acetaldehyde emission } \\
\hline CLM-MEGAN2.1 & Qian 2006 & CLM4-SP & CLM4 & PFT average & 21 & This study \\
\hline GEOS-MEGAN2.1 & GEOS & GEOS & GEOS & PFT average & 23 & Millet et al. (2010) \\
\hline \multicolumn{7}{|l|}{ Acetone emission } \\
\hline CLM-MEGAN2.1 & Qian 2006 & CLM4-SP & CLM4 & PFT average & 40 & This study \\
\hline GEOS-MEGAN2.0 & GEOS & GEOS & GEOS & PFT average & 35 & Jacob et al. (2002) \\
\hline GEOS-MEGAN2.0 & GEOS & GEOS & GEOS & PFT average & 32 & Fischer et al. (2012) \\
\hline
\end{tabular}

model algorithms, driving variables and emission factors had considerably different impacts in the three different models including cases where a change caused an increase in one model and a decrease in another. This result demonstrates the need for a better understanding of model sensitivities to model components and driving variables. In this section we consider the impact of driving variables including solar radiation and temperature (Sect. 2.5.1), soil moisture
(Sect. 2.5.2), and plant functional type and leaf area index (Sect. 2.5.3).

\subsubsection{Solar radiation and temperature}

Wang et al. (2011) assessed the solar radiation data used to drive WRF-AQ/MEGAN2.1 emissions in the Pearl River Delta region of China and found that the downward shortwave radiation simulated by MM5 was considerably higher than observations with a maximum bias of about $150 \mathrm{~W} \mathrm{~m}^{-2}$. 
They attributed this to the lack of aerosol impacts on solar radiation in MM5. Another likely contributor is the errors in model simulations of clouds. Solar radiation fields for air quality models, e.g. CMAQ and CAMx, are typically calculated from WRF or MM5 output using interface processors, such as Meteorology-Chemistry Interface Processor (MCIP). A comparison of isoprene emission estimated using both satellite-based and WRF/MCIP-estimated solar radiation in WRF-AQ/MEGAN2.1 is illustrated in Figure 2 and shows that using WRF/MCIP solar radiation results in North American isoprene emissions that are overestimated by $37 \%$. The overestimation is much higher in specific regions and during hours of peak emission. A comparison of isoprene emission estimates for clear sky conditions was conducted to avoid complications of different cloud distributions in the two datasets. The results show isoprene emissions based on WRF/MCIP solar radiation estimates are higher across the region. This indicates that the difference in solar radiation is not due to variable cloud fraction estimates but is because WRF did not capture the thin high-level baroclinic shield of cirrostratus or altostratus occurring at 6 to $9 \mathrm{~km}$ above sea level. The cloud thickness (approximately $300 \mathrm{~m}$ ) is considered thin when it is compared to 1 to $2 \mathrm{~km}$ layer depth at this altitude and cannot be resolved in the meteorological model. This may be minimized by model simulations that accurately incorporate cloud observations. Even if models can correctly simulate average cloud cover there may be errors due to the non-linear response of emissions under conditions of scattered clouds. An alternative is using satellite based estimates of photosynthetically active radiation (PAR, http://www.atmos.umd.edu/ srb/par/03satellite.htm). Pinker et al. (2003) found that this satellite PAR dataset is in good agreement with ground observations. The satellite PAR is based on actual cloud cover that avoids bias from modeled solar radiation. Using satellite PAR also eliminates uncertainty in the factor used to convert from solar radiation to PAR.

BVOC emissions are highly sensitive to variations in temperature resulting in errors associated with inaccuracies in the temperature data used to drive MEGAN emissions. Wang et al. (2011) assessed the temperature data that they used to simulate biogenic VOC emissions in the Pearl River Delta and found an average bias of about $2{ }^{\circ} \mathrm{C}$ that was associated with an error in isoprene emissions of $\sim 23 \%$. Guenther et al. (2006) found similar differences from using alternative sources of temperature data compiled in global datasets.

\subsubsection{Soil moisture}

The shutdown of a plant's physiological processes in response to drought can lead to an initial increase in emission followed by a decrease and then termination of isoprene emission (Beckett et al., 2012; Pegoraro et al., 2004). MEGAN2.1 simulates the influence of soil moisture on isoprene emission with a simple algorithm, based on the obser- vations of Pegoraro et al. (2004), that relates emission activity to soil moisture and wilting point (the soil moisture below which plants cannot extract water from soil). Guenther et al. (2006) used the Chen and Dudhia (2001) global wilting point dataset as a model input, along with NCEP (National Centers for Environmental Prediction) weather data, for driving this algorithm. The Chen and Dudhia dataset was developed for use with regional MM5 and global NCEP weather models. Müller et al. (2008) found that when using ECMWF (European Centre for Medium-Range Weather Forecasts) global weather model, it was necessary to use the ECMWF wilting point dataset. This finding demonstrates the need to use wilting point values that are appropriate for the soil moisture model used to drive MEGAN rather than using the Chen and Dudhia dataset for all weather models. MEGAN2.1 does not account for the influence of soil moisture on the emissions of BVOC other than isoprene.

\subsubsection{Plant functional type and leaf area index}

Variations in BVOC emission factors are accounted for in MEGAN2.1 either by inputting gridded emission maps or by using PFT data and the PFT emission factors compiled in Table 2. The PFT distributions are also used to determine parameters used for canopy environment models. MEGAN2.1 uses the CLM4 PFT scheme described in Table 3. A global database of CLM4 PFT fraction distributions is available for use with the CLM4 model (http://www.cesm.ucar.edu/) and can also be used to drive WRF-AQ/MEGAN2.1 simulations. The global CLM4 PFT database is available with 10' (about $20 \mathrm{~km}$ ) resolution which is suitable for many regional modeling studies.

Higher resolution data is desirable for some regional modeling studies. A high resolution $(60 \mathrm{~m})$ PFT database using the CLM4 PFT scheme was generated for the US for the year 2008 and is available with the MEGAN2.1 input data (http://bai.acd.ucar.edu/MEGAN/). The database was created by combining the National Land Cover Dataset (NLCD, Homer et al., 2004) and the Cropland Data Layer (see http://nassgeodata.gmu.edu/CropScape/), which are based on 30-m LANDSAT-TM satellite data, with vegetation species composition data from the Forest Inventory and Analysis (see www.fia.fs.fed.us ) and the soil database of the Natural Resources Conservation Services (see http://sdmdataaccess. nrcs.usda.gov/ ). The processing included adjusting the NLCD tree cover estimates in urban areas to account for the substantial underestimation of the LANDSAT-TM data (Duhl et al., 2012). This was accomplished using the regionally specific adjustment factors for urban NLCD developed by Greenfield et al. (2009) using high resolution imagery.

MEGAN uses LAI to quantify the amount of foliage at a given location and uses changes in LAI to estimate the age of the foliage. LAI data for driving MEGAN can be obtained from dynamic vegetation models or from satellite datasets. Some models, including CLM4, have LAI estimates 
separately for each PFT which can improve MEGAN simulations in regions (e.g., an oak-pine forest) with co-located high isoprene-emitting PFT (temperate broadleaf deciduous tree) and low isoprene-emitting PFT (temperate needleleaf evergreen tree) that have very different LAI seasonal patterns. Satellite LAI data that can be used to drive MEGAN include the NASA MODIS data and the European SPOT/VEGETATION data. Garrigues et al. (2008) compared these two products with ground observations and found that each product performed better in some ways (e.g., SPOT generally agreed better with observations but MODIS was better at getting the high LAI values in forests). It should be noted that the NASA MODIS team has an active effort to improve the MODIS LAI product and different versions of the MODIS data can result in substantially different estimates of light independent emissions. A $10 \%$ change in LAI results in a $10 \%$ change in emissions of light independent emissions of BVOC. The impact on emissions of light-dependent emissions becomes less when LAI is greater than 3 because emissions are limited by incoming solar radiation. We compared MODISv5 LAI to the MODIS LAI used for MEGAN v2.04 and found that the average western US LAI values ranged from $\sim 20 \%$ higher in June, July and August to $1 \%$ lower in March. The differences varied considerably among regions. The increase was greatest in the conifer dominated forests of the Rocky Mountains and Pacific Northwest and less in grasslands and shrublands. The MODISv5 cropland LAI was about a factor of 2 lower outside the growing season in some croplands and slightly higher during the growing season. The MODISv5 LAI is 20 to $40 \%$ lower in some, but not all, California oak woodlands resulting in a $20 \%$ or more decrease in isoprene emission estimated with MEGAN2.1.

The WRF-AQ/MEGAN2.1 allows the use of 8-day average satellite observations while the previous version (MEGAN2.04) was driven by monthly LAI data. Although the 8-day LAI can provide a more detailed representation of seasonal LAI variations, monthly data tends to capture the major features. The 8-day product is expected to be most useful during periods of rapid LAI change.

\section{$3 \quad$ MEGAN2.1 emission estimates}

The MEGAN2.1 algorithms have been incorporated into CLM4 (Lawrence et al., 2011) so that all driving variables are determined by the land surface model at each model timestep. CLM4 can be run as a stand-alone model, or coupled to the Community Atmosphere Model with chemistry (CAM-chem; Lamarque et al., 2012) or the full CESM. CLM4 can also be run either with a dynamic carbon-nitrogen cycle which calculates LAI (CLM-CN), or in a mode using specified LAI from MODIS satellite observations (CLMSP). Meteorology used to drive MEGAN can be specified using observations or reanalysis or calculated on-line using an atmospheric model (free-running). Table 5 shows that us- ing these various options (calculated or prescribed LAI, freerunning or specified meteorology) can result in significant differences in MEGAN-calculated biogenic emissions.

CLM-SP was used to calculate MEGAN2.1 global annual emission totals for the year 2000, shown in Table 6, using PFT average emission factors, specified LAI, Qian et al. (2006) atmospheric forcing, and $\mathrm{CO}_{2}$ concentrations fixed at $367 \mathrm{ppm}$. We use this as our standard global simulation constrained by observed land cover (CLM-SP) and meteorology (Qian et al., 2006). The annual global isoprene emission of $535 \mathrm{Tg}$ is slightly less than the $568 \mathrm{Tg}$ (equivalent to $503 \mathrm{Tg}$ carbon) of isoprene estimated by Guenther et al. (1995) and is within $5 \%$ of the values estimated by two other models (Arneth et al., 2011). This estimate is in the middle of the range of reported values for different weather and land cover inputs, 350 to $769 \mathrm{Tg} \mathrm{yr}^{-1}$, calculated with MEGAN2.0 and summarized in Table 5.

The global annual monoterpene emission of $157 \mathrm{Tg}$ estimated using MEGAN2.1 within CLM4 is a little higher than the $144 \mathrm{Tg}$ (127 Tg carbon) estimate of Guenther et al. (1995). The MEGAN2.1 emissions are somewhat higher in the tropics and somewhat lower in temperate and boreal regions in comparison to Guenther et al. (1995). Table 5 shows that the CLM4 model simulation with the CLM-CN option, which provides model-calculated LAI, results in global total monoterpenes that are $19 \%$ higher than with CLM-SP (Lawrence et al., 2011). In contrast, the CLM-CN resulted in isoprene emissions that are 6\% lower than with CLMSP. This indicates that CLM-CN tends to produce higher LAI in monoterpene dominated regions and lower LAI in isoprene dominated regions. The global annual monoterpene emission reported by Schurgers et al. (2009) is a factor of 5 lower than the MEGAN2.1 estimate using CLM4. Schurgers et al. (2009) showed that differences due to the monoterpene emission model used (see Table 5) had only a small (7\%) difference in the estimated emissions. This suggests that the differences in driving variables and emission factors are responsible for these very different estimates of monoterpene emissions.

Table 5 shows that the MEGAN2.1 methanol and acetaldehyde emissions are similar regardless of whether they are driven by CLM4 or by GEOS-Chem or IMAGES2. The CLM4 annual global estimate of methanol is within $10 \%$ of the values reported by Stavrakou et al. (2010) for MEGAN2.1 embedded in the IMAGES2 global atmospheric chemistry model. Similarly, the global annual acetaldehyde emission estimated by CLM4 is within $10 \%$ of the estimate of Millet et al. (2010) when running MEGAN2.1 embedded in the GEOS-Chem global atmospheric chemistry model. The small differences in simulated emissions can be attributed to differences in driving variables and canopy environment models. The MEGAN2.1 methanol emission estimate is almost the same as the global estimate calculated by Galbally and Kirstine (2002). 
The CLM4 annual global estimate of about $4 \mathrm{Tg} \mathrm{yr}^{-1}$ of formic acid and $5 \mathrm{Tg} \mathrm{yr}^{-1}$ of formaldehyde are considerably lower than the total biogenic source, $\sim 100 \mathrm{Tg} \mathrm{yr}^{-1}$ including primary and secondary biogenic sources, estimated from the analysis of satellite observations by Stavrakou et al. (2012). Stavrakou et al. (2012), could not distinguish between direct emission and the atmospheric oxidation of biogenic VOC so a higher direct emission source cannot be ruled out. Recent eddy covariance measurements by DiGangi et al. (2012) suggest a more substantial emission of formaldehyde from the top of a forest canopy than what is estimated by MEGAN2.1. This could be a result of oxidation within the forest canopy which would underestimate the input of total reactive organics to the above canopy atmosphere. The CLM4 estimate of about $40 \mathrm{Tg} \mathrm{yr}^{-1}$ of acetone is $14 \%$ (compared to Jacob et al., 2002) to $25 \%$ (compared to Fischer et al., 2012) higher than the values derived using global model inversions.

Figure 3 shows the January and July global distributions of isoprene, $\alpha$-pinene, acetone, ethene, and $\beta$-caryophyllene emissions. The results are similar to distributions reported for earlier studies with emissions that are generally higher in regions of high biomass density during periods of warm and sunny weather. Differences between the various compounds are also due to PFT specific emission behavior. For example, Australia is a relatively high source of isoprene, $\alpha$-pinene and $\beta$-caryophyllene. While the uncertainties are large, we expect the model to capture the major features that are determined by weather and land cover. The greatest uncertainties are in the land cover average emission factors which are the cause of much of the differences in the estimated distributions of the different compounds shown in Fig. 3.

Figure 4 illustrates regional differences in annual emissions and shows that, in comparison to the Southern Hemisphere, the Northern Hemisphere has several orders of magnitude higher MBO emission, slightly more ethene emission, about the same acetone emission, and $20 \%$ to $25 \%$ lower isoprene, $\alpha$-pinene and $\beta$-caryophyllene emission. The higher MBO emission is due to the relatively high fraction of MBO emitting species in North America. The large contribution of South America to isoprene, $\alpha$-pinene and acetone emission is due in large part to the year-round growing season and high biomass of the Amazon tropical forest. The somewhat lower contribution to ethene is due to the similar ethene emission capacity of different PFTs.

A comparison of MEGAN2.1 estimates calculated using CLM4 and WRF-AQ is shown in Fig. 5. The WRF-AQ simulation uses an emission factor map that accounts for species composition variability within PFTs (e.g., distinguishing between low emitting maple trees and high emitting oak trees), while the CLM4 simulation has a constant emission factor for each PFT. The higher resolution $(36 \times 36 \mathrm{~km}) \mathrm{WRF}$ $\mathrm{AQ}$ and lower resolution CLM4 $(1.9 \times 2.5 \mathrm{deg}, \sim 200 \mathrm{~km})$ model simulations demonstrate the expected finer details for the WRF-AQ results due to higher spatial resolution. The
Table 6. Global annual total emissions simulated for the year 2000 using MEGAN2.1 algorithms in CLM4.

\begin{tabular}{|c|c|c|}
\hline $\begin{array}{l}\text { Compound } \\
\text { Class }\end{array}$ & Compounds & $\begin{array}{c}\text { Emissions } \\
\left(\mathrm{Tg} \mathrm{yr}^{-1}\right)\end{array}$ \\
\hline Isoprene & Isoprene & 535 \\
\hline$\alpha$-Pinene & $\alpha$-Pinene & 66.1 \\
\hline$t$ - $\beta$-Ocimene & $t$ - $\beta$-Ocimene & 19.4 \\
\hline$\beta$-Pinene & $\beta$-Pinene & 18.9 \\
\hline Limonene & Limonene & 11.4 \\
\hline Sabinene & Sabinene & 9.0 \\
\hline Myrcene & Myrcene & 8.7 \\
\hline 3-Carene & 3-Carene & 7.1 \\
\hline \multirow[t]{4}{*}{ Other Monoterpenes } & Camphene & 4.0 \\
\hline & $\beta$-phellandrene & 1.5 \\
\hline & Terpinolene & 1.3 \\
\hline & Additional 31 monoterpenes & 14.9 \\
\hline$\alpha$-Farnesene & $\alpha$-Farnesene & 7.1 \\
\hline$\beta$-Caryophyllene & $\beta$-Caryophyllene & 7.4 \\
\hline \multirow[t]{4}{*}{ Other Sesquiterpenes } & $\beta$-Farnescene & 4.0 \\
\hline & $\alpha$-Humulene & 2.1 \\
\hline & $\alpha$-Bergamotene & 1.3 \\
\hline & Additional 27 sesquiterpenes & 7.1 \\
\hline 232-MBO & 232-MBO & 2.2 \\
\hline Methanol & Methanol & 99.6 \\
\hline Acetone & Acetone & 43.7 \\
\hline \multirow[t]{5}{*}{ Bidirectional VOC } & Ethanol & 20.7 \\
\hline & Acetaldehyde & 20.7 \\
\hline & Formaldehyde & 5.0 \\
\hline & Acetic acid & 3.7 \\
\hline & Formic acid & 3.7 \\
\hline \multirow[t]{5}{*}{ Stress VOC } & Ethene & 26.9 \\
\hline & cis-3-hexenal & 4.9 \\
\hline & DMNT & 4.9 \\
\hline & cis-3-hexenol & 2.9 \\
\hline & Additional 11 stress VOC & 7.8 \\
\hline \multirow[t]{5}{*}{ Other VOC } & Propene & 15.8 \\
\hline & Butene & 8.0 \\
\hline & Homosalate & 2.0 \\
\hline & Geranyl acetone & 0.8 \\
\hline & Additional 45 other VOC & 5.5 \\
\hline Total VOC & Sum of 146 VOC & 1007 \\
\hline $\mathrm{CO}$ & $\mathrm{CO}$ & 81.6 \\
\hline Total & $\mathrm{VOC}$ and $\mathrm{CO}$ & 1089 \\
\hline
\end{tabular}

CLM4 has higher maximum monoterpene emissions and lower maximum isoprene emissions, probably due to the difference between using emission factor maps and using PFT average emission factors.

Coarse spatial resolution of input temperature and light variables can result in errors in emissions when arithmetic average values are used to drive these non-linear emission responses. Guenther (2012) found that even in regions with substantial $\left(>8^{\circ} \mathrm{C}\right)$ small scale temperature differences, increasing the spatial resolution from $100 \mathrm{~km}$ to $1 \mathrm{~km}$ had a fairly small $(-4 \%)$ impact on isoprene emissions when a constant landscape average emission capacity was assumed. A larger (12 to $20 \%$ ) impact was estimated when temperature and landscape emission factors were correlated, such as in regions where higher elevations have cooler temperatures and a higher forested fraction with greater BVOC emissions. 

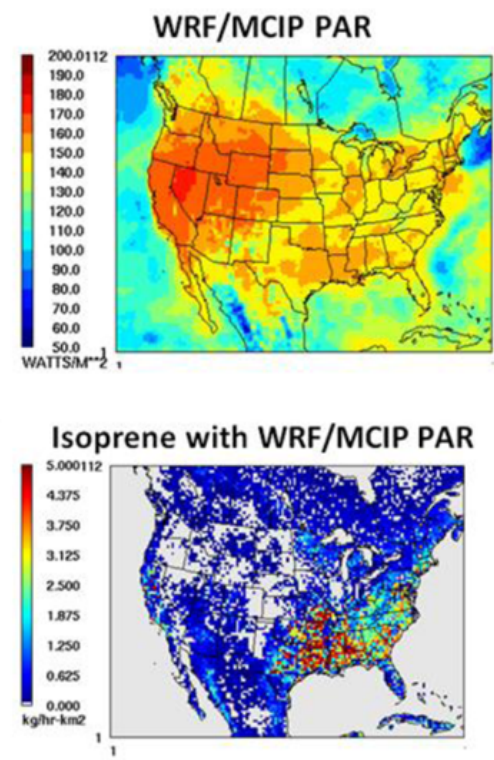
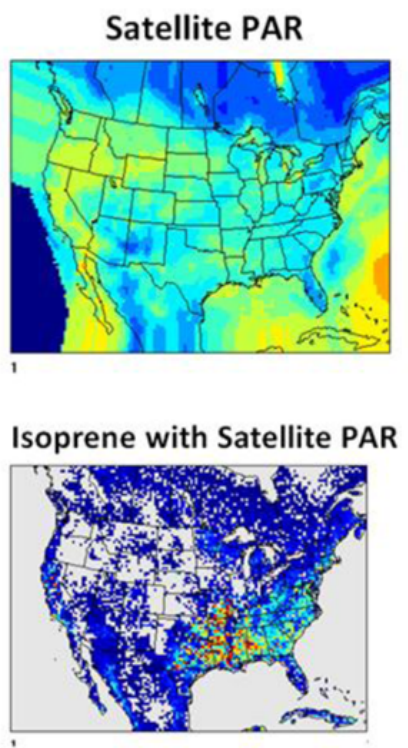

PAR Percent Difference
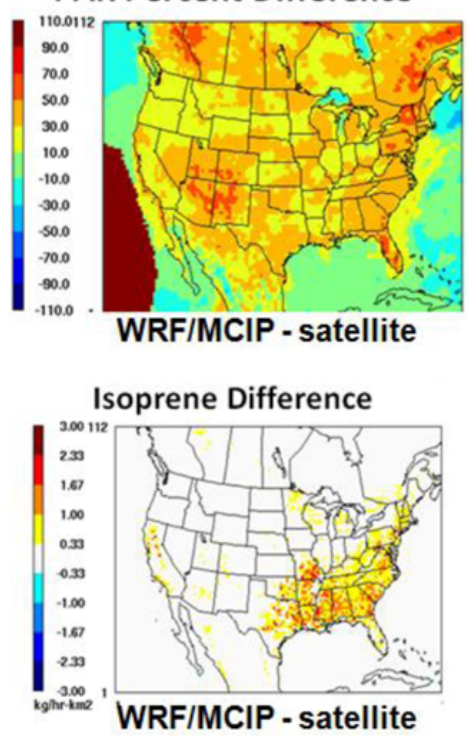

Fig. 2. 3-18 July 2008, period average estimates of PAR $\left(\mathrm{W} \mathrm{m}^{-2}\right)$ from WRF/MCIP (top left) and satellite (top middle) and percent difference for WRF/MCIP - Satellite (top right) and associated isoprene emissions $\left(\mathrm{kg} \mathrm{h}^{-1} \mathrm{~km}^{-2}\right)$ using MEGAN2.1 in WRF-AQ driven by WRF/MCIP PAR (bottom left) and satellite PAR (bottom middle) and difference (bottom right).

\section{Atmospheric biogenic compounds not included in MEGAN}

Chemical species continue to be added to the list of known atmospheric biogenic compounds and it is likely that there are additional important compounds that have not yet been identified. Some compounds have escaped detection because they cannot be observed with the measurement techniques used for some studies such as preconcentration, thermal desorption and gas chromatography with flame ionization detection. Additional compounds began to be identified when gas chromatography with detection by mass spectrometry became more widely available. The development and application of Proton Transfer Reaction Mass Spectrometry (PTRMS) provided an important tool for identifying additional BVOC and their oxidation products (Karl et al., 2008). The continued development and application of analytical techniques for additional BVOC, especially semi-volatile compounds, is needed to identify more compounds.

In addition to having the appropriate analytical tools, the detection of additional BVOC requires extensive spatial and seasonal emission surveys. For example, MBO is a regionally dominant emission in western North America but has negligible emissions in other regions. Significant emissions of some compounds occur only in response to specific stresses, while others are associated with phenological events. These compounds would likely be missed by the short-term measurements characteristic of most BVOC studies.

Atmospheric BVOC are of interest primarily because of their impact on important atmospheric constituents including oxidants and particles. The importance of undetected BVOC can be constrained by measuring the loss of oxidants and growth rate of particles and comparing these observations with expected rates based on measurements of compounds that can be detected. These observations can provide evidence for the existence of undetected compounds. For example, Di Carlo et al. (2004) were unable to account for the observed $\mathrm{OH}$ reactivity above a forest canopy in northern Michigan and concluded that unidentified BVOC were the most likely candidates for this "missing OH reactivity". This was suggested by the observation that the amount of missing reactivity responded to temperature in a manner that closely followed the expected behavior of BVOC emissions. It was also noted that this was a rural area with few local air pollution sources. The missing $\mathrm{OH}$ reactivity was about equal to the known $\mathrm{OH}$ reactivity which was dominated by isoprene. Subsequent studies measured a more comprehensive suite of $\mathrm{OH}$-reactive constituents but still found that the missing $\mathrm{OH}$ reactivity is about half of the total at rural sites and considerably less at urban sites (Lou et al., 2010). Kim et al. (2011) revisited the same Michigan site studied by Di Carlo et al. (2004) and used enclosure measurements to quantify the missing $\mathrm{OH}$ reactivity of the BVOC emissions of individual plant species. They concluded that primary biogenic emissions were not responsible for the missing $\mathrm{OH}$ reactivity and that BVOC oxidation products were the most likely source.

Kurpius and Goldstein (2003) estimated individual components of the ozone flux to a pine plantation and concluded that a large flux of unknown BVOC (an order of magnitude 

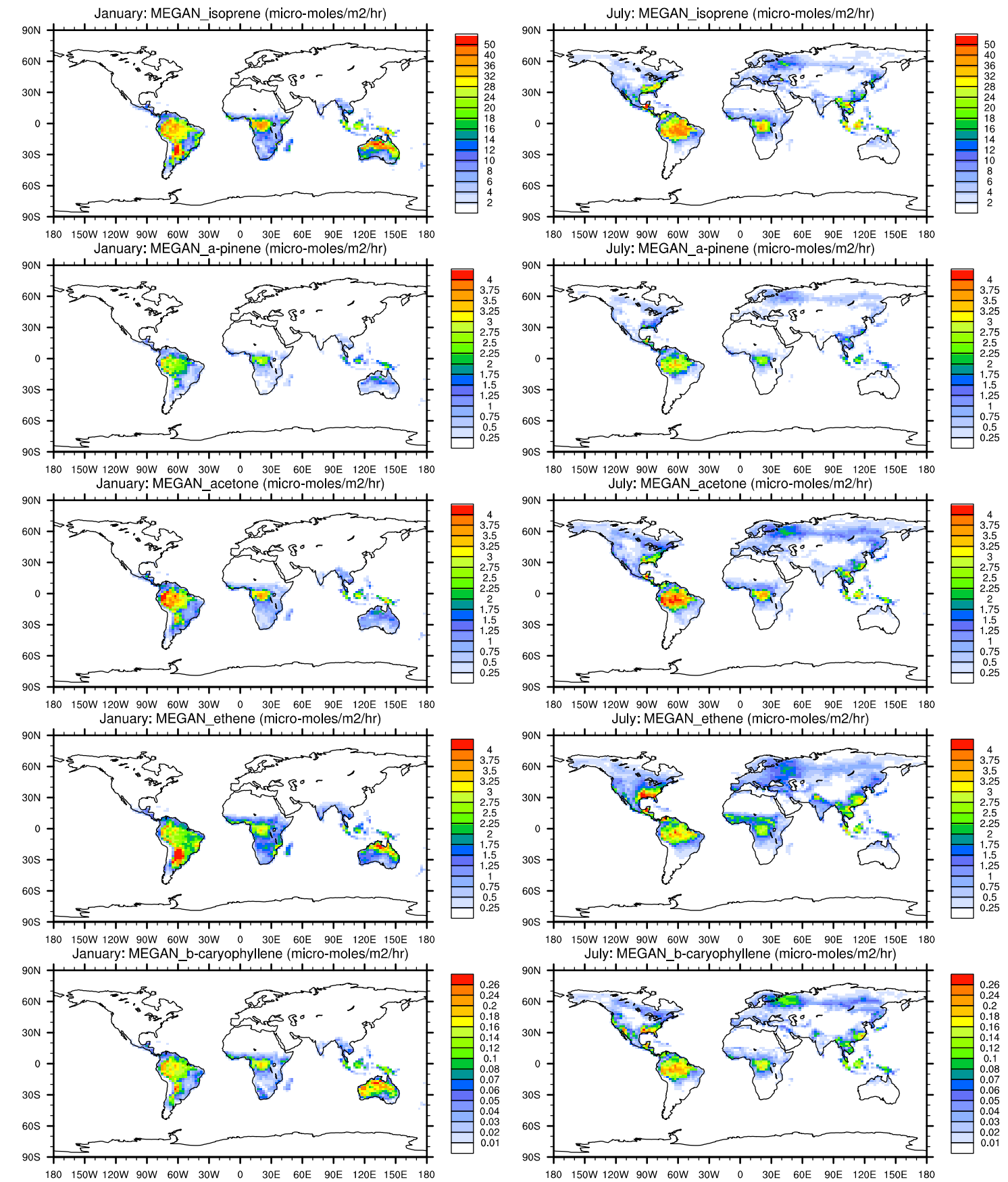

Fig. 3. January and July 2000 global emissions of isoprene, $\alpha$-pinene, acetone, ethene and $\beta$-caryophyllene simulated with MEGAN 2.1 algorithms using CLM4.

higher than the known VOC) was needed to explain the observed ozone depletion near the surface. They also reviewed other reported ozone flux measurements and found that the existence of a large flux of unknown BVOC is not inconsistent with observations at other sites. However, the missing ozone-reactivity flux estimate is highly dependent on estimates of the other components, and additional measure- ments, such as vertical divergence of ozone flux, are needed to constrain these estimates. Holzinger et al. (2005) report measurements of unidentified compounds at the same site which could represent a large flux, if they are reaction products with a low yield, or a small flux, if they are primary emissions. Additional studies are needed to identify and determine the importance of any unknown primary BVOC 


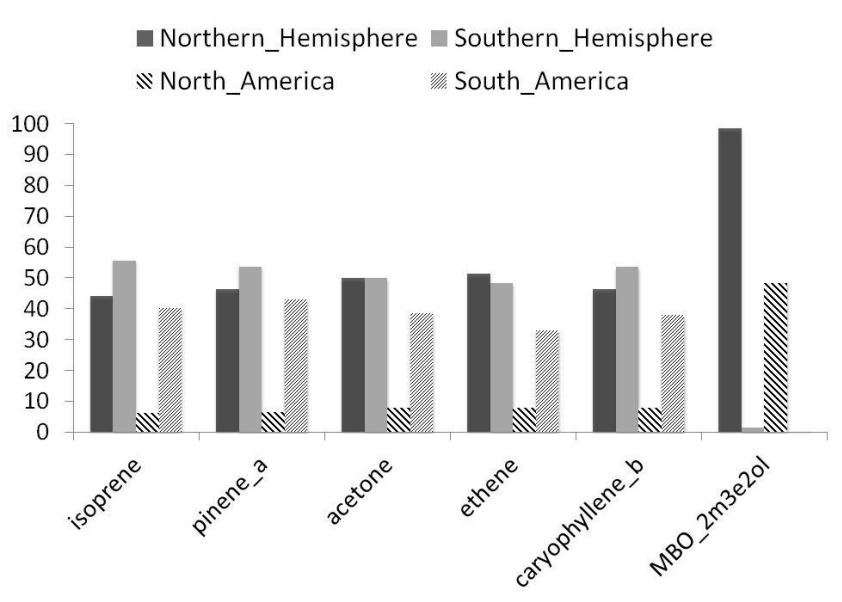

Fig. 4. Regional contributions to global total emissions of selected compounds.

emissions. This should include enclosure measurements of total $\mathrm{OH}$ and ozone reactivity of individual plant species.

\section{BVOC emission uncertainties}

Lamb et al. (1987) provided a simple analysis of the uncertainties associated with their US BVOC emission inventory. They concluded that the major contributors to the overall uncertainty were the emission rate measurements (30 to $55 \%$ error depending on the technique used), emission algorithm $(200 \%)$, biomass densities ( $25 \%)$ and land use distributions $(15 \%)$. Their approach did not use normalized emission factors which caused them to attribute a majority of the uncertainty to their emission algorithm rather than emission factors. They then estimated the overall uncertainty as the square root of the sum of the squares of these four individual uncertainties which results in an overall uncertainty of $\sim 210 \%$. This first quantitative assessment of BVOC emission uncertainties provided general guidance on the accuracy of BVOC emission estimates.

Hanna et al. (2005) attempted to conduct a more thorough quantitative assessment of BVOC emission uncertainties by using a Monte Carlo probabilistic approach to estimate the uncertainties associated with the BEIS3 BVOC emission model estimates. They estimated the individual uncertainties associated with the area averaged emission factor, emission algorithm parameters, and model inputs. The $95 \%$ confidence range on their calculated uncertainty in isoprene emission was about one order of magnitude while the calculated uncertainty for monoterpenes and other VOC was only $20 \%$. The apparent reason for this difference is that the isoprene emission algorithm had more parameters than the monoterpene and other VOC algorithm. This demonstrates the limitations of assigning uncertainties to known parameters when the greatest uncertainties may be associated with unknown factors controlling emissions.
Satellite-based estimates of formaldehyde columns have been used with global atmospheric chemistry models to calculate top-down model estimates of global monthly isoprene emissions. Shim et al. (2005) reported a first estimate of $641 \mathrm{Tg} \mathrm{yr}^{-1}$ using one year of GOME satellite data. Stavrakou et al. (2009) made a more detailed analysis with a decade of formaldehyde columns including data from both the GOME and SCIAMACHY satellites. Their comparison of top-down and bottom-up isoprene emissions indicated that MEGAN2.0 was an improvement over the Guenther et al. (1995) estimates. However, they found that the calculated emissions are highly dependent on the satellite product, the retrieval methods, and the chemistry and transport model used to relate formaldehyde concentration to isoprene emission. Warneke et al. (2010) conducted a top-down estimation approach using aircraft observations of isoprene concentrations. The uncertainties in both satellite and aircraft topdown model approaches have uncertainties of about a factor of 2 (Warneke et al., 2010; Marais et al., 2012). Bottom up isoprene emission models tend to be within a factor of 2 of the top-down estimates suggesting that a factor for 2 is a reasonable estimate of the uncertainty associated with bottomup isoprene emissions. Warneke et al. (2010) noted that this can be considered good agreement given that anthropogenic emission estimates often have errors of more than a factor of 2.

Global methanol (Jacob et al., 2005; Millet et al., 2008; Stavrakou et al., 2011) acetone (Jacob et al., 2002; Fischer et al., 2012) and acetaldehyde (Millet et al., 2010) emission estimates have been assessed by adjusting the a priori estimates of global three-dimensional chemistry and transport models using surface and aircraft concentration measurements through an inversion analysis. The Stavrakou et al. (2011) study also included global distributions from satellite measurements. While studies of these compounds are complicated by anthropogenic and biomass burning sources, terrestrial biogenic sources are a major contributor to their global emission and so modeled concentration distributions are sensitive to the assumed BVOC emissions. All of these studies report estimates of global emissions, shown in Table 5, that are within $50 \%$ of the values estimated using MEGAN2.1 and most are within $25 \%$. These should not be considered as entirely independent evaluations, since the inversion studies start with the MEGAN bottom-up emissions, but they do provide an indication that the MEGAN estimates can generally explain the observed atmospheric concentration distributions.

Recent studies have provided evidence that formaldehyde and formic acid emissions could be much larger than those estimated by MEGAN2.1. The Stavrakou et al. (2012) analysis of satellite data suggest that formic acid emissions are two to three times higher than estimated from known sources. They show that $90 \%$ of formic acid has a biogenic origin. However, they could not determine if this was associated with a direct emission or if it is due to the atmospheric 

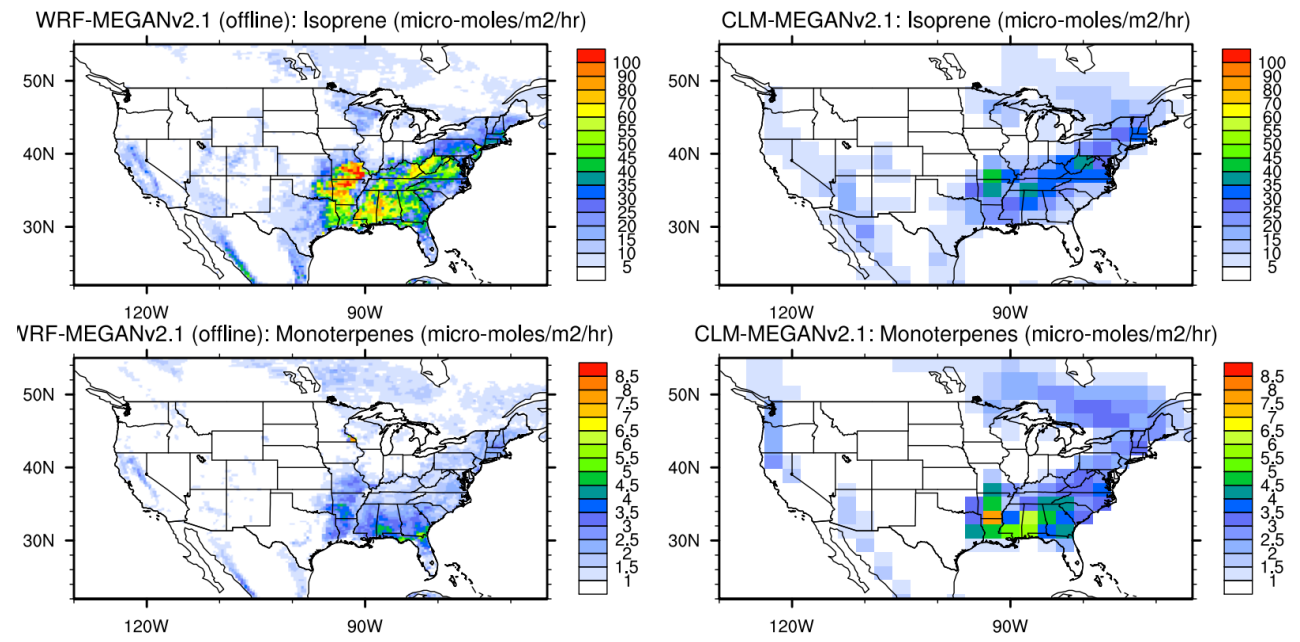

Fig. 5. MEGAN2.1 estimates of US isoprene and monoterpene emissions calculated using WRF-AQ and CLM4.

oxidation of terpenoids. DiGangi et al. (2011) recently reported the first whole canopy fluxes of formaldehyde measured by eddy covariance. The above canopy flux, a net emission, was much higher than predicted from enclosure measurements which may indicate that the measured above canopy flux includes both primary emissions and within canopy production. Additional measurements to constrain formic acid and formaldehyde fluxes are needed.

The nearly 150 compounds included in MEGAN2.1 can be placed into three broad uncertainty categories. The first category includes isoprene, methanol, acetone and acetaldehyde. These compounds have been assessed by global concentration distribution studies that provide some confidence that MEGAN global annual totals are within a factor of 2 based on top down emission estimates. Compounds for which above canopy fluxes have been reported, but no annual global assessment has been made, include $\alpha$-pinene, $\beta$-pinene, myrcene, sabinene, limonene, 3 -carene, $t$ - $\beta$-ocimene, camphene, ethene, propene, butene, methyl salicylate, and 232methyl butenol. The Lamb et al. (1987) uncertainty estimate of a factor of three can be associated with the annual global emission of these compounds. A higher uncertainty should be associated with annual global emissions of all other BVOC. Note that these uncertainties are for annual global emissions and the uncertainty for a specific time and location, especially those landscapes and seasons that have not been investigated, can be much greater.

\section{Summary and conclusions}

MEGAN2.1 provides a flexible scheme for estimating biogenic emissions from terrestrial ecosystems. The global total BVOC flux of about $1000 \mathrm{Tg}$ and the chemical speciation ( $\sim 50 \%$ isoprene, $\sim 15 \%$ monoterpenes) is similar to results from previous models although emissions for specific loca- tions and days may be very different. A dozen compounds have annual global emissions exceeding $1 \%$ of the global total and together they comprise $\sim 80 \%$ of the total flux. Isoprene has been the most studied of these compounds. In contrast, there are relatively few studies of $\mathrm{CO}$, ethene, propene and ethanol emissions that can be used to parameterize or evaluate their emissions. It is clear that isoprene is the globally dominant BVOC and should continue to be the focus of $B V O C$ emissions research although other compounds with a greater capacity for producing aerosol matter (e.g., monoterpenes and sesquiterpenes) or impacting the upper atmosphere (e.g., methyl halides) may have equally or even more important roles in specific earth system processes. In addition, compounds such as MBO may have a small annual global emission but are important for specific regions and seasons.

MEGAN2.1 does not include a generic "other VOC" category as was the case for previous models (e.g., Guenther et al., 1995). Instead MEGAN includes only specific compounds so that they can be used in atmospheric chemistry schemes. Many of the compounds listed in Table 1 have relatively low estimated emission rates and so contribute little to the total estimated BVOC flux. The relatively large uncertainties in these rates do not rule out the possibility of higher contributions and these compounds should be considered in future emission measurement studies.

The uncertainties associated with the emission factors assigned to different landscape types are the largest contributor to the overall biogenic VOC emission estimate uncertainty. Uncertainties in land cover and meteorological driving variables are of a similar magnitude as uncertainties associated with model algorithms. Uncertainties associated with the global annual emissions of some compounds (isoprene, methanol, acetone and acetaldehyde) are about a factor of two while estimates of uncertainties are a factor of three or higher for other compounds. 
The algorithms used to account for the major drivers of emission variability (e.g., temperature, $\mathrm{PPFD}$ and $\mathrm{CO}_{2}$ ) provide a reasonable approximation of emission response but the lack of quantitative algorithms for describing stress response is a significant limitation for predicting emissions of some BVOC. A systematic effort to conduct leaf and canopy scale measurements, including both tower-based flux measurements of temporal variations and airborne-based flux measurements of spatial variations, is required to improve these estimates of emissions and the associated uncertainties.

Acknowledgements. The National Center for Atmospheric Research is sponsored by the US National Science Foundation. C. L. H. acknowledges support from NSF grant ATM-0929282. X. W. was partly supported by the National Nature Science Foundation of China and Guangdong Provincial joint key project (U0833001).

Edited by: H. Tost

\section{References}

Arey, J., Winer, A. M., Atkinson, R., Aschmann, S. M., Long, W. D., and Morrison, C. L.: The emission of (Z)-3-hexen-1-ol, (Z)3-hexenylacetate and other oxygenated hydrocarbons from agricultural plant species, Atmos. Environ., 25A, 1063-1075, 1991.

Arneth, A., Schurgers, G., Lathiere, J., Duhl, T., Beerling, D. J., Hewitt, C. N., Martin, M., and Guenther, A.: Global terrestrial isoprene emission models: sensitivity to variability in climate and vegetation, Atmos. Chem. Phys., 11, 8037-8052, doi:10.5194/acp-11-8037-2011, 2011.

Baghi, R., Helmig, D., Guenther, A., Duhl, T., and Daly, R.: Contribution of flowering trees to urban atmospheric biogenic volatile organic compound emissions, Biogeosciences, 9, 3777-3785, doi:10.5194/bg-9-3777-2012, 2012.

Baker, B., Guenther, A., Greenberg, J., Goldstein, A., and Fall, R.: Canopy fluxes of 2-methyl-3-buten-2-ol over a ponderosa pine forest by relaxed eddy accumulation: Field data and model comparison, J. Geophys. Res.-Atmos., 104, 26107-26114, 1999.

Baker, B., Guenther, A., Greenberg, J., and Fall, R.: Canopy level fluxes of 2-methyl-3-buten-2-ol, acetone, and methanol by a portable relaxed eddy accumulation system, Environ. Sci. Technol., 35, 1701-1708, 2001.

Bates, T. S., Lamb, B. K., Guenther, A., Dignon, J., and Stoiber, R. E.: Sulfur emissions to the atmosphere from natural sources, J. Atmos. Chem., 14, 315-337, 1992.

Beckett, M., Loreto, F., Velikova, V., Brunetti, C., Di Ferdinando, M., Tattini, M., Calfapeitra, C., and Farrant, J. M.: Photosynthetic limitations and volatile and non-volatile isoprenoids in the poikilochlorophyllous resurrection plant Xerophyta humilis during dehydration and rehydration, Plant Cell Environ., online first, doi:10.1111/j.1365-3040.2012.02536.x, 2012.

Benjamin, M. T., Sudol, M., Bloch, L., and Winer, A. M.: Lowemitting urban forests: A taxonomic methodology for assigning isoprene and monoterpene emission rates, Atmos. Environ., 30, 1437-1452, 1996.
Burr, K. E., Wallner, S. J., and Tinus, R. W.: Ethylene and ethane evolution during cold acclimation and deacclimation of ponderosa pine, Can. J. Forest Res., 21, 601-605, 1991.

Chen, F. and Dudhia, J.: Coupling an advanced land surfacehydrology model with the Penn State - NCAR MM5 modeling system, Part I: Model implementation and sensitivity, Mon. Weather Rev., 129, 569-585, 2001.

Connick, W., Bradow, J., and Legendre, M.: Identification and bioactivity of volatile allelochemicals from amaranth residues, J. Agric. Food Chem., 37, 792-796, 1989.

Derwent, R. G., Jenkin, M. E., Passant, N. R., and Pilling, M. J.: Photochemical ozone creation potentials (POCPs) for different emission sources of organic compounds under European conditions estimated with a Master Chemical Mechanism, Atmos. Environ., 41, 2570-2579, 2007.

Di Carlo, P., Brune, W. H., Martinez, M., Harder, H., Lesher, R., Ren, X. R., Thornberry, T., Carroll, M. A., Young, V., Shepson, P. B., Riemer, D., Apel, E., and Campbell, C.: Missing OH reactivity in a forest: Evidence for unknown reactive biogenic VOCs, Science, 304, 722-725, 2004.

DiGangi, J. P., Boyle, E. S., Karl, T., Harley, P., Turnipseed, A., Kim, S., Cantrell, C., Maudlin III, R. L., Zheng, W., Flocke, F., Hall, S. R., Ullmann, K., Nakashima, Y., Paul, J. B., Wolfe, G. M., Desai, A. R., Kajii, Y., Guenther, A., and Keutsch, F. N.: First direct measurements of formaldehyde flux via eddy covariance: implications for missing in-canopy formaldehyde sources, Atmos. Chem. Phys., 11, 10565-10578, doi:10.5194/acp-1110565-2011, 2011.

Dudareva, N., Negre, F., Nagegowda, D. A., and Orlova, I.: Plant volatiles: Recent advances and future perspectives, Crit. Rev. Plant Sci., 25, 417-440, 2006.

Duhl, T. R., Helmig, D., and Guenther, A.: Sesquiterpene emissions from vegetation: a review, Biogeosciences, 5, 761-777, doi:10.5194/bg-5-761-2008, 2008.

Duhl, T. R., Guenther, A., and Helmig, D.: Estimating urban vegetation cover fraction using Google Earth®images, J. Land Use Sci., 7, 311-329, doi:10.1080/1747423X.2011.587207, 2012.

Engelberth, J., Alborn, H. T., Schmelz, E. A., and Tumlinson, J. H.: Airborne signals prime plants against insect herbivore attack, P. Natl. Acad. Sci. USA, 101, 1781-1785, doi:10.1073/pnas.0308037100, 2004.

Fall, R.: Biogenic emissions of volatile organic compounds from higher plants, in Reactive hydrocarbons in the atmosphere, edited by: Hewitt, C. N., 41-96, Academic Press, New York, 1999.

Fischer, E. V., Jacob, D. J., Millet, D. B., Yantosca, R. M., and Mao, J.: The role of the ocean in the global atmospheric budget of acetone, Geophys. Res. Lett., 39, L01807, doi:10.1029/2011GL050086, 2012.

Folberth, G. A., Hauglustaine, D. A., Lathière, J., and Brocheton, F.: Interactive chemistry in the Laboratoire de Météorologie Dynamique general circulation model: model description and impact analysis of biogenic hydrocarbons on tropospheric chemistry, Atmos. Chem. Phys., 6, 2273-2319, doi:10.5194/acp-62273-2006, 2006.

Fruekilde, P., Hjorth, J., Jensen, N. R., Kotzias, D., and Larsen, B.: Ozonolysis at vegetation surfaces: A source of acetone, 4oxopentanal, 6-methyl-5-hepten-2-one and geranyl acetone, Atmos. Environ., 32, 1893-1902, 1998. 
Galbally, I. E. and Kirstine, W.: The Production of Methanol by Flowering Plants and the Global Cycle of Methanol, J. Atmos. Chem., 43, 195-229, 2002.

Garrigues, S., Lacaze, R., Baret, F., Morisette, J. T., Weiss, M., Nickeson, J. E., Fernandes, R., Plummer, S., Shabanov, N. V., Myneni, R. B., Knyazikhin, Y., and Yang, W.: Validation and intercomparison of global Leaf Area Index products derived from remote sensing data, J. Geophys. Res.-Biogeosci., 113, G02028, doi:10.1029/2007JG000635, 2008.

Gent, P. R., Danabasoglu, G., Donner, L. J., Holland, M. M., Hunke, E. C., Jayne, S. R., Lawrence, D. M., Neale, R. B., Rasch, P. J., Vertenstein, M., Worley, P. H., Yang, Z.-L., and Zhang, M.: The Community Climate System Model Version 4, J. Climate, 24, 4973-4991, 2011.

Geron, C., Guenther, A., Sharkey, T., and Arnts R. R.: Temporal variability in basal isoprene emission factor, Tree Physiol., 20, 799-805, 2000.

Goldan, P. D., Kuster, W. C., Fehsenfeld, F. C., and Montzka, S. A.: The observation of a C5 alcohol emission in a North American pine forest, Geophys. Res. Lett., 20, 1039-1042, 1993.

Goldstein, A. H. and Galbally, I. E.: Known and unexplored organic constituents in the Earth's atmosphere, Environ. Sci. Technol., 41, 1514-1521, 2007.

Goldstein, A. H., Fan, S. M., Goulden, M. L., Munger, J. W., and Wofsy, S. C.: Emissions of ethene, propene, and 1-butene by a midlatitude forest, J. Geophys. Res.-Atmos., 101, 9149-9157, 1996.

Graedel, T. E.: Terpenoids in the atmosphere, Rev. Geophys. Space Phys., 17, 937-947, 1979.

Gray, D. W., Goldstein, A. H., and Lerdau, M. T.: The influence of light environment on photosynthesis and basal methylbutenol emission from Pinus ponderosa, Plant Cell Environ., 28, 1463 1474, doi:10.1111/j.1365-3040.2005.01382.x, 2005.

Greenberg, J. P., Guenther, A. B., Pétron, G., Wiedinmyer, C., Vega, O., Gatti, L. V., Tota, J., and Fisch, G.: Biogenic VOC emissions from forested Amazonian landscapes, Glob. Change Biol., 10, 651-662, 2004.

Greenfield, E., Nowak, D. J., and Walton, J. T.: Assessment of 2001 NLCD percent tree and impervious cover estimates, Photogramm. Eng. Remote. Sense., 75, 1279-1286, 2009.

Guenther, A. B.: Upscaling biogenic VOC emissions from leaves to landscapes, in: Biology, Controls and Models of Tree Volatile Organic Compound Emissions, edited by: Niinemets, U. and Monson, R., Springer Tree Physiology series, 2012.

Guenther, A. B., Monson, R. K., and Fall, R.: Isoprene and monoterpene emission rate variability: Observations with eucalyptus and emission rate algorithm development, J. Geophys. Res.-Atmos., 96, 10799-10808, 1991.

Guenther, A. B., Zimmerman, P. R., Harley, P. C., Monson, R. K., and Fall, R.: Isoprene and monoterpene emission rate variability: Model evaluations and sensitivity analyses, J. Geophys. Res.Atmos., 98, 12609-12617, 1993.

Guenther, A. B., Hewitt, C. N., Erickson, D., Fall, R., Geron, C., Graedel, T., Harley, P., Klinger, L., Lerdau, M., McKay, W. A., Pierce, T., Scholes, B., Steinbrecher, R., Tallamraju, R., Taylor, J., and Zimmerman, P.: A global model of natural volatile organic compound emissions, J. Geophys. Res.-Atmos., 100, 8873-8892, 1995.
Guenther, A. B., Baugh, B., Brasseur, G., Greenberg, J., Harley, P., Klinger, L., Serça, D., and Vierling, L.: Isoprene emission estimates and uncertainties for the Central African EXPRESSO study domain, J. Geophys. Res.-Atmos., 104, 30625-30639, 1999.

Guenther, A. B., Geron, C., Pierce, T., Lamb, B., Harley, P., and Fall, R.: Natural emissions of non-methane volatile organic compounds, carbon monoxide, and oxides of nitrogen from North America, Atmos. Environ., 34, 2205-2230, 2000.

Guenther, A. B., Karl, T., Harley, P., Wiedinmyer, C., Palmer, P. I., and Geron, C.: Estimates of global terrestrial isoprene emissions using MEGAN (Model of Emissions of Gases and Aerosols from Nature), Atmos. Chem. Phys., 6, 3181-3210, doi:10.5194/acp-63181-2006, 2006.

Hanna, S. R., Russell, A. G., Wilkinson, J. G., Vukovich, J., and Hansen, D. A.: Monte Carlo estimation of uncertainties in BEIS3 emission outputs and their effects on uncertainties in chemical transport model predictions, J. Geophys. Res.-Atmos., 110, D01302, doi:10.1029/2004JD004986, 2005.

Harley, P., Fridd-Stroud, V., Greenberg, J., Guenther A., and Vasconcellos, P.: Emission of 2-methyl-3-buten-2-ol by pines: A potentially large natural source of reactive carbon to the atmosphere, J. Geophys. Res.-Atmos., 103, 25479-25486, 1998.

Heald, C. L., Wilkinson, M. J., Monson, R. K., Alo, C. A., Wang, G., and Guenther, A.: Response of isoprene emission to ambient $\mathrm{CO}_{2}$ changes and implications for global budgets, Glob. Change Biol., 15, 1127-1140, 2009.

Heiden, A. C., Kobel, K., Komenda, M., Koppmann, R., Shao, M., and Wildt, J.: Toluene emissions from plants, Geophys. Res. Lett., 26, 1283-1286, 1999.

Helmig, D., Klinger, L. F., Guenther, A., Vierling, L., Geron, C., and Zimmerman, P.: Biogenic volatile organic compound emissions (BVOCs) I. Identifications from three continental sites in the U.S., Chemosphere, 38, 2163-2187, 1999.

Helmig, D., Ortega, J., Guenther, A., Herrick, J. D., and Geron, C.: Sesquiterpene emissions from loblolly pine and their potential contribution to biogenic aerosol formation in the Southeastern US, Atmos. Environ., 40, 4150-4157, 2006.

Holzinger, R., Lee, A., Paw, K. T., and Goldstein, U. A. H.: Observations of oxidation products above a forest imply biogenic emissions of very reactive compounds, Atmos. Chem. Phys., 5, 67-75, doi:10.5194/acp-5-67-2005, 2005.

Homer, C., Huang, C. Q., Yang, L. M., Wylie, B., and Coan, M.: Development of a 2001 National Land-Cover Database for the United States, Photogramm. Eng. Rem. Sens., 70, 829-840, 2004.

Isidorov, V. A., Zenkevich, I. G., and Ioffe, B. V.: Volatile organic compounds in the atmosphere of forests, Atmos. Environ., 19, $1-8,1985$.

Jacob, D. J., Field, B. D., Jin, E. M., Bey, I., Li, Q., Logan, J. A., Yantosca, R. M., and Singh, H. B.: Atmospheric budget of acetone, J. Geophys. Res.-Atmos., 107, 4100, doi:10.1029/2001JD000694, 2002.

Jacob, D. J., Field, B. D., Li, Q., Blake, D. R., de Gouw, J., Warneke, C., Hansel, A., Wisthaler, A., Singh, H. B. and Guenther, A.: Global budget of methanol: Constraints from atmospheric observations, J. Geophys. Res.-Atmos., 110, D08303, doi:10.1029/2004JD005172, 2005. 
Jacovides, C. P., Tymvios, F. S., Assimakopoulos, V. D., and Kaltsounides, N. A.: The dependence of global and diffuse PAR radiation components on sky conditions at Athens, Greece, Agr. Forest Meteorol., 143, 277-287, 2007.

Janson, R., De Serves, C., and Romero, R.: Emission of isoprene and carbonyl compounds from a boreal forest and wetland in Sweden, Agr. Forest Meteorol., 98-99, 671-681, 1999.

Kant, M. R., Bleeker, P. M., Van Wijk, M., Schuurink, R. C., and Haring, M. A.: Plant Volatiles in Defence, Adv. Bot. Res., 51, 613-666, 2009.

Karl, T., Guenther, A., Lindinger, C., Jordan, A., Fall, R., and Lindinger, W.: Eddy covariance measurements of oxygenated volatile organic compound fluxes from crop harvesting using a redesigned proton-transfer-reaction mass spectrometer, J. Geophys. Res.-Atmos., 106, 24157-24167, 2001.

Karl, T., Spirig, C., Rinne, J., Stroud, C., Prevost, P., Greenberg, J., Fall, R., and Guenther, A.: Virtual disjunct eddy covariance measurements of organic compound fluxes from a subalpine forest using proton transfer reaction mass spectrometry, Atmos. Chem. Phys., 2, 279-291, doi:10.5194/acp-2-279-2002, 2002.

Karl, T., Potosnak, M., Guenther, A., Clark, D., Walker, J., Herrick, J. D., and Geron, C.: Exchange processes of volatile organic compounds above a tropical rain forest: Implications for modeling tropospheric chemistry above dense vegetation, J. Geophys. Res.-Atmos., 109, D18306, doi:10.1029/2004JD004738, 2004.

Karl, T., Guenther, A., Yokelson, R. J., Greenberg, J., Potosnak, M., Blake, D. R., and Artaxo, P.: The tropical forest and fire emissions experiment: Emission, chemistry, and transport of biogenic volatile organic compounds in the lower atmosphere over Amazonia, J. Geophys. Res.-Atmos., 112, D18302, doi:10.1029/2007JD008539, 2007.

Karl, T., Guenther, A., Turnipseed, A., Patton, E. G., and Jardine, K.: Chemical sensing of plant stress at the ecosystem scale, Biogeosciences, 5, 1287-1294, doi:10.5194/bg-5-1287-2008, 2008.

Karl, M., Guenther, A., Köble, R., Leip, A., and Seufert, G.: A new European plant-specific emission inventory of biogenic volatile organic compounds for use in atmospheric transport models, Biogeosciences, 6, 1059-1087, doi:10.5194/bg-6-1059-2009, 2009.

Keenan, T. F., Grote, R., and Sabaté, S.: Overlooking the canopy: The importance of canopy structure in scaling isoprenoid emissions from the leaf to the landscape, Ecol. Model., 222, 737-747, 2011.

Kesselmeier, J.: Exchange of short-chain oxygenated volatile organic compounds (VOCs) between plants and the atmosphere: A compilation of field and laboratory studies, J. Atmos. Chem., 39, 219-233, 2001.

Kesselmeier, J., Bode, K., Hofmann, U., Müller, H., Schäfer, L., Wolf, A., Ciccioli, P., Brancaleoni, E., Cecinato, A., Frattoni, M., Foster, P., Ferrari, C., Jacob, V., Fugit, J. L., Dutaur, L., Simon, V., and Torres, L.: Emission of short chained organic acids, aldehydes and monoterpenes from Quercus ilex L. and Pinus pinea L. in relation to physiological activities, carbon budget and emission algorithms, Atmos. Environ., 31, 119-133, 1997.

Kim, S., Karl, T., Guenther, A., Tyndall, G., Orlando, J., Harley, P., Rasmussen, R., and Apel, E.: Emissions and ambient distributions of Biogenic Volatile Organic Compounds (BVOC) in a ponderosa pine ecosystem: interpretation of PTR-MS mass spectra, Atmos. Chem. Phys., 10, 1759-1771, doi:10.5194/acp-101759-2010, 2010.
Kim, S., Guenther, A., Karl, T., and Greenberg, J.: Contributions of primary and secondary biogenic VOC total $\mathrm{OH}$ reactivity during the CABINEX (Community Atmosphere-Biosphere INteractions Experiments)-09 field campaign, Atmos. Chem. Phys., 11, 86138623, doi:10.5194/acp-11-8613-2011, 2011.

Kirstine, W., Galbally, I., Ye, Y., and Hooper, M.: Emissions of volatile organic compounds (primarily oxygenated species) from pasture, J. Geophys. Res.-Atmos., 103, 10605-10619, 1998.

Klinger, L. F., Li, Q.-J., Guenther, A. B., Greenberg, J. P., Baker, B., and Bai, J.-H.: Assessment of volatile organic compound emissions from ecosystems of China, J. Geophys. Res.-Atmos., 107, 4603, doi:10.1029/2001JD001076, 2002.

Knudsen, J. T., Eriksson, R., Gershenzon, J., and Ståhl, B.: Diversity and distribution of floral scent, Bot. Rev., 72, 1-120, 2006.

König, G., Brunda, M., Puxbaum, H., Hewitt, C. N., Duckham, S. C., and Rudolph, J.: Relative contribution of oxygenated hydrocarbons to the total biogenic VOC emissions of selected midEuropean agricultural and natural plant species, Atmos. Environ., 29, 861-874, 1995.

Kolosova, N., Gorenstein, N., Kish, C., and Dudareva, N.: Regulation of circadian methyl benzoate emission in diurnally and nocturnally emitting plants, Plant Cell, 13, 2333-2347, doi:10.1105/tpc.13.10.2333, 2001.

Krauss, M., Wilcke, W., Martius, C., Bandeira, A. G., Garcia, M. V. B., and Amelung, W.: Atmospheric versus biological sources of polycyclic aromatic hydrocarbons (PAHs) in a tropical rain forest environment, Environ. Pollut., 135, 143-154, 2005.

Kreuzwieser, J., Schnitzler, J.-P., and Steinbrecher, R.: Biosynthesis of organic compounds emitted by plants, Plant Biol., 1, 149-159, 1999.

Kurpius, M. R. and Goldstein, A. H.: Gas-phase chemistry dominates $\mathrm{O}_{3}$ loss to a forest, implying a source of aerosols and hydroxyl radicals to the atmosphere, Geophys. Res. Lett., 30, 1371, doi:10.1029/2002GL016785, 2003.

Lamarque, J.-F., Bond, T. C., Eyring, V., Granier, C., Heil, A., Klimont, Z., Lee, D., Liousse, C., Mieville, A., Owen, B., Schultz, M. G., Shindell, D., Smith, S. J., Stehfest, E., Van Aardenne, J., Cooper, O. R., Kainuma, M., Mahowald, N., McConnell, J. R., Naik, V., Riahi, K., and van Vuuren, D. P.: Historical (1850-2000) gridded anthropogenic and biomass burning emissions of reactive gases and aerosols: methodology and application, Atmos. Chem. Phys., 10, 7017-7039, doi:10.5194/acp10-7017-2010, 2010.

Lamarque, J.-F., Emmons, L. K., Hess, P. G., Kinnison, D. E., Tilmes, S., Vitt, F., Heald, C. L., Holland, E. A., Lauritzen, P. H., Neu, J., Orlando, J. J., Rasch, P. J., and Tyndall, G. K.: CAM-chem: description and evaluation of interactive atmospheric chemistry in the Community Earth System Model, Geosci. Model Dev., 5, 369-411, doi:10.5194/gmd-5-369-2012, 2012.

Lamb, B., Guenther, A., Gay, D., and Westberg, H.: A national inventory of biogenic hydrocarbon emissions, Atmos. Environ., 21, 1695-1705, 1987.

Lawrence, D. M., Oleson, K. W., Flanner, M. G., Thorton, P. E., Swenson, S. C., Lawrence, P. J., Zeng, X., Yang, Z.-L., Levis, S., Skaguchi, K., Bonan, G. B., and Slater, A. G.: Parameterization improvements and functional and structural advances in version 4 of the Community Land Model, J. Adv. Model. Earth Sys., 3, 2011MS000045, doi:10.1029/2011ms000045, 2011. 
Lizaso, J. I., Batchelor, W. D., Boote, K. J., and Westgate, M. E.: Development of a leaf-level canopy assimilation model for CERES-Maize, Agron. J., 97, 722-733, 2005.

Lou, S., Holland, F., Rohrer, F., Lu, K., Bohn, B., Brauers, T., Chang, C. C., Fuchs, H., Häseler, R., Kita, K., Kondo, Y., Li, X., Shao, M., Zeng, L., Wahner, A., Zhang, Y., Wang, W., and Hofzumahaus, A.: Atmospheric $\mathrm{OH}$ reactivities in the Pearl River Delta - China in summer 2006: measurement and model results, Atmos. Chem. Phys., 10, 11243-11260, doi:10.5194/acp-10-11243-2010, 2010.

MacDonald, R. C. and Fall, R.: Detection of substantial emissions of methanol from plants to the atmosphere, Atmos. Environ., Part A-General Topics, 27, 1709-1713, 1993.

MacDonald, R. C. and Fall, R.: Acetone emission from conifer buds, Phytochemistry, 34, 991-994, 1993b.

Marais, E. A., Jacob, D. J., Kurosu, T. P., Chance, K., Murphy, J. G., Reeves, C., Mills, G., Casadio, S., Millet, D. B., Barkley, M. P., Paulot, F., and Mao, J.: Isoprene emissions in Africa inferred from OMI observations of formaldehyde columns, Atmos. Chem. Phys., 12, 6219-6235, doi:10.5194/acp-12-62192012, 2012.

Martin, R. S., Villanueva, I., Zhang, J., and Popp, C. J.: Nonmethane hydrocarbon, monocarboxylic acid, and low molecular weight aldehyde and ketone emissions from vegetation in central New Mexico, Environ. Sci. Technol., 33, 2186-2192, 1999.

Matsunaga, S. N., Guenther, A. B., Potosnak, M. J., and Apel, E. C.: Emission of sunscreen salicylic esters from desert vegetation and their contribution to aerosol formation, Atmos. Chem. Phys., 8, 7367-7371, doi:10.5194/acp-8-7367-2008, 2008.

Millet, D. B., Jacob, D. J., Custer, T. G., de Gouw, J. A., Goldstein, A. H., Karl, T., Singh, H. B., Sive, B. C., Talbot, R. W., Warneke, C., and Williams, J.: New constraints on terrestrial and oceanic sources of atmospheric methanol, Atmos. Chem. Phys., 8, 68876905, doi:10.5194/acp-8-6887-2008, 2008.

Millet, D. B., Guenther, A., Siegel, D. A., Nelson, N. B., Singh, H. B., de Gouw, J. A., Warneke, C., Williams, J., Eerdekens, G., Sinha, V., Karl, T., Flocke, F., Apel, E., Riemer, D. D., Palmer, P. I., and Barkley, M.: Global atmospheric budget of acetaldehyde: 3-D model analysis and constraints from in-situ and satellite observations, Atmos. Chem. Phys., 10, 3405-3425, doi:10.5194/acp-10-3405-2010, 2010.

Müller, J.-F., Stavrakou, T., Wallens, S., De Smedt, I., Van Roozendael, M., Potosnak, M. J., Rinne, J., Munger, B., Goldstein, A., and Guenther, A. B.: Global isoprene emissions estimated using MEGAN, ECMWF analyses and a detailed canopy environment model, Atmos. Chem. Phys., 8, 1329-1341, doi:10.5194/acp-81329-2008, 2008.

Niinemets, U.: Mild versus severe stress and BVOCs: thresholds, priming and consequences, Trends Plant Sci., 15, 145-153, 2010.

Otter, L., Guenther, A., Wiedinmyer, C., Fleming, G., Harley, P. and Greenberg, J.: Spatial and temporal variations in biogenic volatile organic compound emissions for Africa south of the equator, J. Geophys. Res.-Atmos., 108, 8505, doi:10.1029/2002JD002609, 2003.

Owen, S., Boissard, C., Street, R. A., Duckham, S. C., Csiky, O., and Hewitt, C. N.: Screening of 18 Mediterranean plant species for volatile organic compound emissions, Atmos. Environ., 31, 101-117, 1997.
Pegoraro, E., Rey, A., Greenberg, J., Harley, P., Grace, J., Malhi, Y., and Guenther, A.: Effect of drought on isoprene emission rates from leaves of Quercus virginiana Mill, Atmos. Environ., 38, 6149-6156, 2004.

Pfister, G. G., Emmons, L. K., Hess, P. G., Lamarque, J.-F., Orlando, J. J., Walters, S., Guenther, A., Palmer, P. I. and Lawrence, P. J.: Contribution of isoprene to chemical budgets: A model tracer study with the NCAR CTM MOZART-4, J. Geophys. Res.-Atmos., 113, D05308, doi:10.1029/2007JD008948, 2008.

Pierce, T., Geron, C., Bender, L., Dennis, R., Tonnesen, G., and Guenther, A.: Influence of increased isoprene emissions on regional ozone modeling, J. Geophys. Res.-Atmos., 103, 2561125629, 1998.

Pinker, R. T., Tarpley, D., Laszlo, I., Mitchell, K. E., Houser, P. R., Wood, E. F., Schaake, J. C., Robock, A., Lohmann, D., Cosgrove, B. A., Sheffield, J., Duan, Q., Luo, L., and Higgins, R. W.: Surface radiation budgets in support of the GEWEX ContinentalScale International Project (GCIP) and the GEWEX Americas Prediction Project (GAPP), including the North American Land Data Assimilation System (NLDAS) project, J. Geophys. Res., 108, 8844, doi:10.1029/2002jd003301, 2003.

Poulton, J. E.: Cyanogenesis in plants, Plant. Physiol., 94, 401-405, 1990.

Puxbaum, H. and König, G.: Observation of dipropenyldisulfide and other organic sulfur compounds in the atmosphere of a beech forest with Allium ursinum ground cover, Atmos. Environ., 31, 291-294, 1997.

Qian, T., Dai, A., Trenberth, K. E., and Oleson, K. W.: Simulation of global land surface conditions from 1948 to 2004, Part I: Forcing data and evaluations, J. Hydrometeorol., 7, 953-975, 2006.

Rhew, R. C., Miller, B. R., and Weiss, R. F.: Natural methyl bromide and methyl chloride emissions from coastal salt marshes, Nature, 403, 292-295, 2000.

Sakulyanontvittaya, T., Duhl, T., Wiedinmyer, C., Helmig, D., Matsunaga, S., Potosnak, M., Milford, J., and Guenther, A.: Monoterpene and sesquiterpene emission estimates for the United States, Environ. Sci. Technol., 42, 1623-1629, 2008.

Savage, T. J., Hristova, M. K., and Croteau, R.: Evidence for an elongation/reduction/C1-elimination pathway in the biosynthesis of n-heptane in xylem of Jeffrey pine, Plant Physiol., 111, 12631269, 1996.

Sawada, S. and Totsuka, T.: Natural and anthropogenic sources and fate of atmospheric ethylene, Atmos. Environ., 20, 821-832, 1986.

Schade, G. W. and Goldstein, A. H.: Fluxes of oxygenated volatile organic compounds from a ponderosa pine plantation, J. Geophys. Res.-Atmos., 106, 3111-3123, 2001.

Schade, G. W., Goldstein, A. H., Gray, D. W., and Lerdau, M. T.: Canopy and leaf level 2-methyl-3-buten-2-ol fluxes from a ponderosa pine plantation, Atmos. Environ., 34, 3535-3544, 2000.

Shim, C., Wang, Y., Choi, Y., Palmer, P. I., Abbot, D. S., and Chance, K.: Constraining global isoprene emissions with Global Ozone Monitoring Experiment (GOME) formaldehyde column measurements, J. Geophys. Res.-Atmos., 110, D24301, doi:10.1029/2004JD005629, 2005.

Shim, C. S., Wang, Y. H., Singh, H. B., Blake, D. R., and Guenther, A. B.: Source characteristics of oxygenated volatile organic compounds and hydrogen cyanide, J. Geophys. Res.-Atmos., 112, D10305, doi:10.1029/2006JD007543, 2007. 
Schurgers, G., Arneth, A., Holzinger, R., and Goldstein, A. H.: Process-based modelling of biogenic monoterpene emissions combining production and release from storage, Atmos. Chem. Phys., 9, 3409-3423, doi:10.5194/acp-9-3409-2009, 2009.

Sive, B. C., Varner, R. K., Mao, H., Blake, D. R., Wingenter, O. W., and Talbot, R.: A large terrestrial source of methyl iodide, Geophys. Res. Lett., 34, L17808, doi:10.1029/2007GL030528, 2007.

Stavrakou, T., Müller, J.-F., De Smedt, I., Van Roozendael, M., van der Werf, G. R., Giglio, L., and Guenther, A.: Evaluating the performance of pyrogenic and biogenic emission inventories against one decade of space-based formaldehyde columns, Atmos. Chem. Phys., 9, 1037-1060, doi:10.5194/acp-9-1037-2009, 2009.

Stavrakou, T., Guenther, A., Razavi, A., Clarisse, L., Clerbaux, C., Coheur, P.-F., Hurtmans, D., Karagulian, F., De Mazière, M., Vigouroux, C., Amelynck, C., Schoon, N., Laffineur, Q., Heinesch, B., Aubinet, M., Rinsland, C., and Müller, J.-F.: First space-based derivation of the global atmospheric methanol emission fluxes, Atmos. Chem. Phys., 11, 4873-4898, doi:10.5194/acp-11-4873-2011, 2011.

Stavrakou, T., Müller, J.-F., Peeters, J., Razavi, A., Clarisse, L., Clerbaux, C., Coheur, P.-F., Hurtmans, D., De Mazière, M., Vigouroux, C., Deutscher, N. M., Griffith, D. W. T., Jones, N., and Paton-Walsh, C.: Satellite evidence for a large source of formic acid from boreal and tropical forests, Nat. Geosci., 5, 2630, 2012.

Stoakley, J. T., Bakke, A., Renwick, J. A. A. and Vité, J. P.: The aggregation pheromone system of the larch bark beetle, Ips cembrae Heer, Z. Angewandte Entomologie, 86, 174-177, doi:10.1111/j.1439-0418.1978.tb01925.x, 1978.

Talbot, R. W., Andreae, M. O., Berresheim, H., Jacob, D. J., and Beecher, K. M.: Sources and sinks of formic, acetic, and pyruvic acids over central Amazonia, 2. Wet season, J. Geophys. Res.Atmos., 95, 16799-16801, 1990.

Tarr, M. A., Miller, W. L., and Zepp, R. G.: Direct carbon monoxide photoproduction from plant matter, J. Geophys. Res.-Atmos., 100, 11403-11413, 1995.

Tarvainen, V., Hakola, H., Hellén, H., Bäck, J., Hari, P., and Kulmala, M.: Temperature and light dependence of the VOC emissions of Scots pine, Atmos. Chem. Phys., 5, 989-998, doi:10.5194/acp-5-989-2005, 2005.

Tava, A., Berardo, N., Cunico, C., Romani, M., and Odoardi, M.: Cultivar differences and seasonal changes of primary metabolites and flavor constituents in tall fescue in relation to palatability, J. Agr. Food Chem., 43, 98-101, 1995.

Tie, X. X., Li, G. H., Ying, Z. M., Guenther, A., and Madronich, S.: Biogenic emissions of isoprenoids and NO in China and comparison to anthropogenic emissions, Sci. Total Environ., 371, 238$251,2006$.
Turlings, T. C. J. and Ton, J.: Exploiting scents of distress: the prospect of manipulating herbivore-induced plant odours to enhance the control of agricultural pests, Curr. Opin. Plant Biol., 9, 421-427, 2006.

Turlings, T. C. J., Lengwiler, U. B., Bernasconi, M. L., and Wechsler, D.: Timing of induced volatile emissions in maize seedlings, Planta, 207, 146-152, 1998.

Wang, X., Situ, S., Guenther, A. B., Chen, F., Wu, Z., and Xia, B.: Spatiotemporal variability of biogenic terpenoid emissions in Pearl River Delta, China, with high-resolution land-cover and meteorological data, Tellus B, 63, 241-254, 2011.

Warneke, C., Karl, T., Judmaier, H., Hansel, A., Jordan, A., Lindinger, W., and Crutzen, P. J.: Acetone, methanol, and other partially oxidized volatile organic emissions from dead plant matter by abiological processes: Significance for atmospheric HOx chemistry, Global Biogeochem. Cy., 13, 9-17, 1999.

Warneke, C., Luxembourg, S. L., de Gouw, J. A., Rinne, H. J. I., Guenther, A. B., and Fall, R.: Disjunct eddy covariance measurements of oxygenated volatile organic compounds fluxes from an alfalfa field before and after cutting, J. Geophys. Res.-Atmos., 107, 4067, doi:10 1029/2001JD000594, 2002.

Watts, S. F.: The mass budgets of carbonyl sulfide, dimethyl sulfide, carbon disulfide and hydrogen sulfide, Atmos. Environ., 34, 761779, 2000.

Wiedinmyer, C., Akagi, S. K., Yokelson, R. J., Emmons, L. K., AlSaadi, J. A., Orlando, J. J., and Soja, A. J.: The Fire INventory from NCAR (FINN): a high resolution global model to estimate the emissions from open burning, Geosci. Model Dev., 4, 625641, doi:10.5194/gmd-4-625-2011, 2011.

Wildt, J., Kobel, K., Schuh-Thomas, G. and Heiden, A. C.: Emissions of oxygenated volatile organic compounds from plants part II: Emissions of saturated aldehydes, J. Atmos. Chem., 45, 173196, 2003.

Wilkinson, M. J., Monson, R. K., Trahan, N., Lee, S., Brown, E., Jackson, R. B., Polley, H. W. , Fay, P. A., and Fall, R.: Leaf isoprene emission rate as a function of atmospheric $\mathrm{CO}_{2}$ concentration, Glob. Change Biol., 15, 1189-1200, 2009.

Yani, A., Pauly, G., Faye, M., Salin, F., and Gleizes, M.: The effect of a long-term water stress on the metabolism and emission of terpenes of the foliage of Cupressus sempervirens, Plant Cell Environ., 16, 975-981, 1993.

Yoshida, Y., Wang, Y., Shim, C., Cunnold, D., Blake, D. R., and Dutton, G. S.: Inverse modeling of the global methyl chloride sources, J. Geophys. Res.-Atmos., 111, D16307, doi:10.1029/2005JD006696, 2006. 